\title{
Do Elections Affect the Composition of Fiscal Policy?
}

\author{
Margarita Katsimi \\ Vassilis Sarantides
}

CESIFO WORKING PAPER No. 2908

CAtegory 2: Public Choice

JANUARY 2010

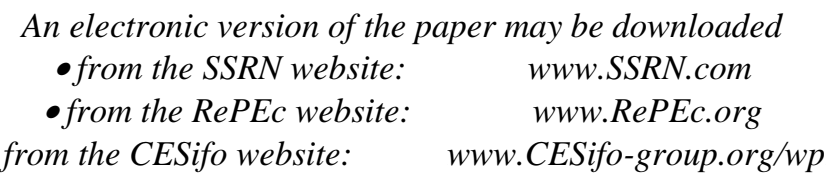




\title{
Do Elections Affect the Composition of Fiscal Policy?
}

\begin{abstract}
This paper investigates the impact of elections on the level and composition of fiscal instruments using a sample of 19 high-income OECD countries that can be characterized as developed, established democracies during the period 1972-1999. We find that elections shift public spending towards current and away from capital expenditures. Moreover, although we find no evidence for an electoral cycle for government deficit and expenditures, we do find a negative effect of elections on revenue. Our results indicate that the fall in revenue in election periods is attributed to a fall in direct taxation. The decomposition of our electoral dummy suggests that fiscal manipulation seems to be concentrated shortly before the elections. Finally, when we distinguish among predetermined and endogenous elections we find that the above results apply only for the predetermined electoral periods while endogenous elections seem to increase the budget deficit and to leave the composition of fiscal policy unaffected.
\end{abstract}

JEL-Code: D72, E62.

Keywords: political budget cycles, elections, composition of fiscal policy, quality of public expenditure.

Margarita Katsimi
Athens University of Economics and
Business
Department of International and European
Economic Studies
Patision Str 76
Greece - Athens 10434
mkatsimi@aueb.gr

Margarita Katsimi Business Economic Studies

reece - Athens 1043

@aueb.gr

\author{
Vassilis Sarantides \\ Athens University of Economics and \\ Business \\ Department of International and European \\ Economic Studies \\ Patision Str 76 \\ Greece - Athens 10434 \\ sarantides@aueb.gr
}

December 2009

Without implicating, we wish to thank George Economides and Thomas Moutos for useful comments and suggestions. 


\section{Introduction}

A growing literature suggests that elections create distortions to economic policy. An important part of this literature focuses on the incentives of office-motivated politicians to manipulate economic variables in order to get re-elected. ${ }^{1}$ This theoretical argument, firstly formulated in the traditional opportunistic model of "political business cycles" of Nordhaus (1975), has been later addressed in a rational expectations framework both in adverse selection models [see e.g., Cukierman and Meltzer (1986), Rogoff and Sibert (1988), and Rogoff (1990)] as well as in moral hazard models [see, in particular, Persson and Tabellini (1990), Shi and Svensson (2006)]. A general feature of rational opportunistic "political budget cycles" (PBC) models is the presence of uncertainty regarding the policymakers' competence. In this environment the incumbent has an incentive to manipulate some fiscal instrument, if voters' expectation regarding her competence depends on the value of this instrument. ${ }^{2}$ Both types of rational PBC models predict a negative electoral impact on taxation ${ }^{3}$. However, aggregate public spending may rise, as the incumbent will have an incentive to increase expenditures in the election period financed by a deficit observed by voters in the postelection period, but it may also fall, as a rise in the incumbent's level of effort will limit 'wasteful' public spending' [Besley and Case (1995)].

The main empirical implications of PBC models have been widely tested. ${ }^{4} \mathrm{~A}$ general conclusion of existing studies is that budget cycles exists in developing countries and in "new" democracies whereas established democracies with more competitive electoral system seem to experience a fiscal revenue cycle (see Brender and Drazen (2005), Persson and Tabellini (2003,chapter 8) and Shi and Svensson (2006)).

Rogoff (1990) was the first to provide a firm theoretical foundation for the possibility of electorally timed shifts in the composition rather than the level of public spending. In the framework of an adverse selection type PBC model, he demonstrates

\footnotetext{
${ }^{1}$ Another part of this literature consists of 'partisan' models, which deal with the behavior of ideologically motivated politicians. Alesina, Roubini, and Cohen (1997) provide a comprehensive review of all branches of political business cycle theory and Drazen (2000).

2 Maley et al (2007) investigate the impact of electoral incentives on capital accumulation and macroeconomic fluctuations in a DSGE framework.

${ }^{3}$ For a discussion of the empirical implications of PBC models see Persson and Tabellini (1990)

${ }^{4}$ For a survey see Mink and de Haan (2005) and Vergne (2009).
} 
that electoral incentives may induce the incumbent to signal her competence by shifting public spending towards more visible government consumption and away from public investment goods. Government consumption expenditures are more visible in the sense that they are observed before elections while capital expenditures (e.g. infrastructure) are mostly long-term projects that will increase voter's utility upon completion. Assuming that the cost of fiscal distortion is higher for the more competent incumbent, a rise in current expenditures in the election period at the cost of lower public investment will signal the high competence of the incumbent if the cost of mimicking this policy is sufficiently high for the less competent policymaker. In a more recent paper Saporiti and Streb (2008) focus on the incumbent's discretion over the budget and show that with a single fiscal authority the incumbent has an incentive to change the composition of public spending in favour of the more visible public good in order to appear competent to the voters and to increase the probability of being re-elected. However, separation of powers can work as a commitment device and may moderate or even eliminate the $\mathrm{PBC}$ under certain conditions regarding the institutional framework.

Several studies attempt to assess empirically the electoral impact on the composition of public spending. Schuknecht (2000), using data on 24 developing countries from 1973 to 2002, finds that PBC are mainly attributed to increased rather than decreased capital expenditures (\% GDP). Additionally, Block (2002), using data on 69 developing countries from 1975 to 1990 , checks if elections affect the share of capital expenditures (\% expenditures). Indeed, his results reveal a deterioration of public investment during the election year. Along the same lines, a recent study of Vergne (2009), using data on 42 developing countries from 1975 to 2001, finds that elections shift the composition of spending towards current expenditures ( $\%$ expenditures) and away from capital expenditures (\% expenditures).

Surprisingly, although the theoretical models of PBC were originally conceived for developed countries, the electoral impact on the composition of fiscal policy has so far been investigated for developing countries. Several arguments support this approach. Schuknecht (1996) suggests that fiscal manipulation in developing countries is more likely because check and balances are weaker. Moreover, the informational asymmetries 
regarding competence that are a crucial assumption of $\mathrm{PBC}$ models may be more plausible in developing countries (see Block (2002)).

On the other hand, it should be stressed that PBC models are all based on the assumption of competitive elections, which is more applicable to "old" democracies, rather than to developing countries many of which are "new" democracies. Indeed, multiparty electoral competition that characterizes developed countries is critical in motivating incumbents to engage in pre-electoral economic policy distortions in order to retain their office. Similarly, the underlying voting behaviour of the PBC models is closer to the voting behaviour of more experienced voters in established democracies rather than to the inexperienced voting behaviour in "new" democracies. Moreover, it is not clear that the assumption of "lower visibility" of capital expenditures conforms to the experience of developing countries. Schuknecht (2000) argues that in developing countries public works projects can be easily started and stopped around elections whereas current expenditures may reflect longer-term commitments. Clearly, this argument is less applicable to developed economies. In fact Block (2002) shows that the hypothesis that elections give rise to a substitution of current for capital expenditures is best applied to the relatively richer countries in his sample of developing and middle-income countries.

Our paper deals with an important question that has not been properly addressed by the relevant literature. Do elections in developed, established democracies affect the composition of fiscal policy? We try to answer this question by looking at the impact of the elections on different types of fiscal expenditure and revenue for a sample of 19 "old" democracies over the period 1972-1999. We classify public expenditures as capital and current expenditures while we decompose tax variables as direct (distortionary) taxation and indirect (non-distortionary) taxation (see Kneller et al. (1999)). At the same time, we provide some new evidence on the electoral cycle of aggregate fiscal variables. We measure electoral uncertainty by constructing two alternative electoral indicators: Following the relevant literature, we construct a dummy variable that receives the value 1 in an election year and 0 otherwise and alternatively, we construct a weighted indicator that allows us to directly control for fluctuations in election dates by taking into account the specific time (month) that elections took place. Although, empirical analysis on the electoral impact on the composition of fiscal policy is usually based on the adverse 
selection model of Rogoff (1990) we easily derive similar propositions regarding the composition of fiscal policy in the framework of the moral hazard model of Shi and Svensson (2006). This is an empirically more relevant theoretical framework since it predicts that all types of incumbent governments will change the composition of fiscal instruments independent of their competence level.

To the best of our knowledge, our paper is novel in the following two aspects: Firstly, we examine the existence of pre-electoral fiscal policy distortions in the composition of public spending using a sample of developed countries that can be considered as established democracies during the entire sample period. Secondly, apart from looking at the composition of public spending we also look at the electoral impact on different tax policy instruments. The electoral impact on the composition of tax instruments has -according to our knowledge- not been empirically tested before for any sample of developed and/or developing countries.

Our main results can be summarized as follows: Firstly, elections seem to shift public expenditures towards current and away from capital expenditures. We find that elections decrease capital and increase current expenditures as a percentage of total expenditures. Moreover, capital expenditures as percentage of GDP fall. Secondly, regarding aggregate fiscal variables, we find no evidence for an electoral cycle for government deficit and expenditures but we do find a negative effect of election on revenue. These results are consistent with existing stylized facts presented by Brender and Drazen (2005) and Shi and Svensson (2006). Thirdly, we find that the fall in revenue in election periods is attributed to a fall in direct taxation. The choice of policymakers to decrease direct rather than indirect taxation could be explained both in terms of 'electoral efficiency' as well as in terms of economic efficiency. One could argue that a fall in direct taxation produces a more 'visible' effect on voters' income compare to a fall in indirect taxation. Moreover, a large literature suggests that decreasing indirect taxation compared to direct taxation will have a positive growth effect through its impact on household's savings and labour supply decisions. ${ }^{5}$ In fact, governments have in recent years become increasingly interested in using indirect taxation to finance a larger share of public spending. Finally, if we distinguish among predetermined and endogenous

\footnotetext{
${ }^{5}$ For a survey of relevant literature see OECD (2006).
} 
elections - in line with the assumptions of our theoretical model - the above results apply only for predetermined electoral periods.

The rest of the paper is organized as follows. Section 2 outlines our theoretical framework. Section 3 describes the empirical setup and presents the empirical results and discusses various sensitivity tests. Finally, section 4 offers some concluding remarks.

\section{The theoretical framework}

The theoretical argument that incumbents will have an incentive to manipulate the economy in order to get re-elected has been addressed in three main consequent frameworks.

In the traditional opportunistic models of "political business cycles" the incumbent boosts the economy before elections by exploiting a traditional Phillips curve leading to electoral cycles in inflation and unemployment [see Nordhaus (1975), Lindbeck (1976) and Tufte (1978)]. In a rational expectations framework, political budget cycles emerge due to the presence of information asymmetries between voters and politicians regarding the competence level of the latter [see e.g., Cukierman and Meltzer (1986), Rogoff and Sibert (1988), and Rogoff (1990)). In these rational opportunistic PBC models a competent incumbent has an incentive to signal her level of competence to voters through fiscal policy in order to increase the probability of being re-elected. In the separating equilibrium of the resulting signalling game, the competent incumbent will distort fiscal policy without being "punished" by rational voters who perceive this distortion as the cost of acquiring information regarding policymakers' competence.

A draw back of the adverse selection type models is the difficulty of testing their empirical implications since they predict budget cycles that will depend on the policymakers' level of competence that is not directly observable. This difficulty is overcome by the moral hazard type models that are also, however, based on the presence of uncertainty regarding the policymakers' competence [see, in particular, Persson and Tabellini (1990), Shi and Svensson (2006)]. In these models the policymaker, irrespectively of her level of competence, has an incentive to manipulate some fiscal instrument thereby affecting voters' expectation regarding her competence. For example, 
in this environment a policymaker will have an incentive to increase expenditures in the election period by increasing the deficit, which will be observed by voters in the postelection period.

This section develops a simple theoretical model that borrows its main features from Shi and Svensson (2006). Shi and Svensson show the impact of elections on government deficit. In our model we neglect debt issuing and introduce public investment as the fiscal policy instrument with relatively lower visibility to voters.

The economy consists of a large number of individuals each of whom derives utility from public goods and private consumption. As in Rogoff (1990) the government produces a "consumption" good (per capita) $g$ and an "investment" good (per capita) $k$. The utility function of voter $i$ in period $t$ is,

$U_{t}^{i}=\sum_{s=t}^{T} \beta^{s-t}\left(c_{s}+u\left(g_{s}\right)+v\left(k_{s}\right)+\delta^{i} x_{s}\right)$

where $v^{\prime}>0, v^{\prime \prime}<0$ and $u>0, u^{\prime \prime}<0, c$ denotes the private consumption good and $x$ takes the value $-(1 / 2)$ if the incumbent is re-elected and $(1 / 2)$ otherwise. As in Shi and Svensson (2006) we assume that voters differ in their preferences on issues other than consumption. This heterogeneity of voters is captured by $\delta$ that is uniformly distributed on $[-1 / 2,1 / 2]$ and reflects the voter's preference on other issues so that if voter $i$ prefers the incumbent (opponent) $\delta^{i}<0(>0)$.

Regarding the political environment, there are two parties competing for office, the one of the incumbent denoted by, in and the opposition party denoted by op. Politicians are office-motivated in the sense that when they derive utility $\mathrm{Z}$ from being in office. Thus, the utility function of political candidate $\mathrm{j}$ is given by,

$W_{t}^{j}=\sum_{s=t}^{T} \beta^{s-t}\left(c_{s}+u\left(g_{s}\right)+v\left(k_{s}\right)+Z_{s}\right)$

Every period each individual is endowed with income y and pays a lump-sum tax $\tau$. Thus, the budget constraint of the government is given by, 
$g_{t}+k_{t+1}=\tau_{t}+\omega_{t}^{j}$

where $\omega_{t}$ denotes the government's level of competence that captures the administrative ability of the government. Given the level of tax revenue a government with a high level of competence is able to produce a higher level of public goods than a government with low competence. We assume that competence is random since the problems the policymaker faces may change over time. Moreover, we assume that competence is persistent in the sense that competence in the post-election period will depend on competence in the pre-election period. Thus, in line with existing literature (see Rogoff (1990), Saporiti and Streb (2008)) we assume that competence follows a first-order moving average process,

$\omega_{t}^{j}=\varepsilon_{t}^{j}+\varepsilon_{t-1}^{j}$

where $E(\varepsilon)=0, \operatorname{Var}(\varepsilon)=\sigma^{2} . \mathrm{F}(\varepsilon)$ and $f(\varepsilon)$ are the distribution function and the density function of $\varepsilon$ respectively with $f(0)>0$. Note that the competence shock represents a source of uncertainty for the government since it is realised after the government policies are set.

\subsection{Equilibrium without political competition}

In the absence of political competition our problem can be broken down into a sequence of static maximization problems where the policymaker in office maximizes equation (2) with respect to $g_{t}$ and $k_{t+1}$ subject to equations (3) and (4). The FOC are given by

$g_{t}=u_{g}^{-1}(1)$

$k_{t+1}=v_{k}^{-1}(1)$

\subsection{Elections}

Let us now assume that elections take place every other period. In that case our assumptions regarding preferences and the stochastic environment allow us to break our problem into a sequence of two-period maximization problems. Our methodology is borrowed by Shi and Svensson (2006). The timing of the events is the following: At the 
beginning of the pre-election period t, the policymaker decides on the level of the public consumption good, $g$ and the level of the public investment good, $k$ that will be consumed in the next period. In the absence of any fiscal rule, policies are set under discretion. After policies are decided the competence shock, $\varepsilon_{t}$ is realised and elections take place at the end of this period. We assume that voters are to some extend imperfectly informed in the sense that before they vote they observe only variables that represent consumption in the current period such as $c_{t}\left(g_{t}\right)$ and $\tau_{t}$, while they only observe the public investment good, $k_{t+1}$ in the next period.

In the post-election period $\mathrm{t}+1$ the timing of events is similar but no elections take place. In addition, the incumbent has no incentive to influence voters' perception about his competence since competence in the next post-election period, $\mathrm{t}+3$ is uncorrelated with competence in period $\mathrm{t}+1$. Thus, the optimal tax rate and the optimal public investment will satisfy the FOCs (5) and (6).

In the election period t voters will vote for the candidate who will offer them the higher utility in period $t+1$. This will depend on their relative preference for the two parties reflected by $\delta$ and on the expected level of the policymaker's competence. Voter's $i$ expected utility if the opposition party is re-elected is given by,

$$
E U_{t+1}^{i}=E_{t}\left(c_{t+1}^{o p}\right)+u\left(g^{*}\right)+E_{t} v\left(k_{t+1}^{o p}\right)+\delta^{i}(1 / 2)
$$

where

$$
E_{t}\left(c_{t+1}^{o p}\right)=y-g *-k *
$$

Similarly if the incumbent is re-elected expected utility in period $t+1$ is

$$
E U_{t+1}^{i}=E_{t}\left(c_{t+1}^{i n}\right)+u\left(g^{*}\right)+E_{t} v\left(k_{t+1}^{i n}\right)-\delta^{i}(1 / 2)
$$

where 
$E_{t}\left(c_{t+1}^{i n}\right)=y-g^{*}-k^{*}+E_{t}\left(\varepsilon_{t}^{i n}\right)$

Note that $\mathrm{g}^{*}$ and $k^{*}$ are the level of the public "consumption" good and public “investment" good that satisfy FOCs (5) and (6), while $k_{t+1}^{i n}=k_{E}^{*}$ is the optimal public investment set by the policymaker in the election period. Following the Shi and Svensson (2006) framework, subtracting (7) from (9) implies that voter $i$ will vote for the incumbent if $E_{t}\left(\varepsilon_{t}^{i n}\right)-\delta^{i} \geq 0$ and given the distribution of $\delta$,

$\operatorname{Pr}\left(E_{t}\left(\varepsilon_{t}^{i n}\right)-\delta^{i} \geq 0\right)=E_{t}\left(\varepsilon_{t}^{i n}\right)+\frac{1}{2}$

We can re-write equation (3) as

$\varepsilon_{t}^{j}=g_{t}+k_{t+1}-\tau_{t}-\varepsilon_{t-1}^{j}$

Since voters can observe $g_{t}$ and $\tau_{t}$ before the elections their estimate for the incumbent's current competence shock, $\hat{\varepsilon_{t}}$ will depend on their estimate for public investment, $\hat{k_{t+1}}$ $\hat{\varepsilon}_{t}^{i n}=g_{t}+\hat{k}_{t+1}-\tau_{t}-\varepsilon_{t-1}^{i n}=\varepsilon_{t}^{i n}+\hat{k}_{t+1}-k_{t+1}$

Thus, the probability that the incumbent will receive at least $50 \%$ of the votes is,

$$
P_{t}=\operatorname{Pr}\left(\varepsilon_{t}^{i n}+\hat{k}_{t+1}-k_{t+1}+\frac{1}{2} \geq \frac{1}{2}\right)=\operatorname{Pr}\left(\varepsilon_{t}^{i n} \geq k_{t+1}-\hat{k}_{t+1}\right)=1-F\left(k_{t+1}-\hat{k}_{t+1}\right)
$$

Our next step is to maximize the two-period utility function of the incumbent with respect to $k_{t+1}$ taking into account equation (14), 


$$
\begin{aligned}
& \max _{k_{t+1}} E_{t}\left[y-g^{*}-k_{t+1}+v\left(k^{*}\right)+u\left(g^{*}\right)+X\right] \\
& +E_{t}\left[1-F\left(k_{t+1}-\hat{k}_{t+1}\right)\right]\left[y-g *-k^{*}+\varepsilon_{t+1}^{i n}+v\left(k_{t+1}\right)+u\left(g^{*}\right)+X\right] \\
& +E_{t} F\left(k_{t+1}-\hat{k}_{t+1}\right)\left[y-g^{*}-k^{*}+\varepsilon_{t+1}^{o p}+v\left(k_{t+1}\right)+u\left(g^{*}\right)+X\right]
\end{aligned}
$$

The FOC is

$$
v^{\prime}\left(k_{t+1}\right)=1+F^{\prime}\left(k_{t+1}-\hat{k}_{t+1}\right) X
$$

In equilibrium $\hat{k}_{t+1}=k_{t+1}=k_{E}^{*}$ so we can write equation (16) as

$$
v^{\prime}\left(k_{E}^{*}\right)=1+f^{\prime}(0) X
$$

Given that $f^{\prime}(0)>0$ and $v^{\prime \prime}<0$, we can conclude from comparing equation (6) with equation (17) that $k_{E}^{*}<k^{*}$. This implies that electoral competition decreases capital spending in the election period. One can see from equation (3) that taxation will also fall ${ }^{6}$.

Concluding, the model's main implication is that the electoral motives of the incumbent when fiscal policy is conducted under discretion will decrease the part of public spending that is 'less visible' in the election period allowing a fall in taxation, which is a 'more visible' fiscal policy instrument. As in Shi and Svensson (2006), in equilibrium this policy is fully expected and has no impact on the incumbent's re-election probability.

\section{Econometric Analysis}

\subsection{Data}

Our sample spans over the period 1972 to 1999 and includes 19 OECD countries ${ }^{7}$ with competitive electoral systems. New Zealand is excluded from the sample due to data unavailability. Additionally, Greece, Portugal and Spain, have been dropped from our

\footnotetext{
${ }^{6}$ Note that the fall in taxation at constant government consumption good, $g$, stems from the way we formulate preferences. We could as easily set up voters' utility function so that taxation remains constant and $g$ increases.

7 The countries of our sample are Australia, Austria, Belgium, Canada, Denmark, Finland, France, Germany, Iceland, Ireland, Italy, Japan, Luxemburg, Netherlands, Norway, Sweden, Switzerland, United Kingdom and United States.
} 
sample since they cannot be considered as established democracies during the entire sample period. These "new" democracies are more prone to fiscal manipulation, since incumbents might be rewarded at the polls if they can "mislead" inexperienced voters by attributing the good economic conditions to their competency. Alternatively, we could have included these countries in our sample and exclude only those election observations which refer to the period that the democracy was in fact "new". However, since as argued by Brender and Drazen (2005), there are doubts about how long the "new democracy" effect persists we opt for excluding the countries.

Our fiscal data refer to the central government level, and are obtained from the "Global Development Network Growth Database". ${ }^{8}$ Primary data for the proceeds are taken from IMF, "Government Financial Statistics" (GFS); and data for GDP come from Global Development Finance and World Development Indicators. In this study we want to check the existence of political cycles in aggregate fiscal data, and whether or not the composition of public spending and taxation is affected by elections. For the aggregate fiscal data, we use central government's expenditures, revenues and budget surplus/deficit (expenditures, revenues and balance, respectively). As a second step, we use the economic classification provided by the GFS database and separate expenditures into public investment and public consumption. In particular, we disaggregate expenditures into capital expenditures (capital) and current expenditures (current). Both aggregated and disaggregated fiscal data are scaled to GDP and expressed as percentages. Finally, in order to test the electoral impact on the composition of total expenditures, we use the same measures expressed as percentages of total expenditures and denoted as capital_exp and current_exp, respectively.

Regarding the tax variables we apply the approach of Kneller et al. (1999) and classify them as direct (distortionary) taxation and indirect (non-distortionary) taxation. Direct taxation includes taxation on income and profits, social security contributions, taxation on payroll and manpower and taxation on property, while indirect taxation includes taxation on domestic goods and services. Again, both direct and indirect taxation

\footnotetext{
${ }^{8}$ An alternative database is OECD Economic Outlook, which, however, provides data from general government accounts. We instead opt for using central government data which are more consistent across countries and time periods. At the same, results for general government accounts that include all levels of government (state, local, central) would be difficult to interpret.
} 
is expressed as percentage of GDP and total revenues, denoted as direct, indirect and direct_rev, indirect_rev, respectively.

Apart from the fiscal variables, in our estimated model we include s number of socio-economic variables, proposed by a previous study of Shi and Svensson (2006). In particular, we use the $\log$ of real per capita GDP $(\lg d p p c)$ and real GDP growth rates (growth), since these variables should capture the possibility that the timing of elections depends on the state of the economy. All macroeconomic data for control variables are obtained from World Bank's "World Development Indicators" (WDI). A complete list of all variables used in our estimations is provided in the Data Appendix.

We measure electoral uncertainty by constructing two alternative electoral indicators. First of all, following the majority of the empirical literature, we construct an election dummy (elec) that receives value 1 in an election year and 0 otherwise. It is important to note that this indicator is not affected by the specific time (month) that the election took place.We use this measure so that our results can be more easily comparable to the $\mathrm{PBC}$ literature. However, many researchers have noticed that if elections take place early in the year, then the dummy variable may be capturing primarily post-electoral effects. One way to deal with this problem with annual data is to construct a pre-election indicator (elec_2) that takes the value of one at the year preceding election and zero otherwise [see e.g., Franzese (2000), Angelopoulos and Economides (2008)]. More precisely: in election year $t$, elec $_{-} 2=\mathrm{x} / 12$ with $\mathrm{x}$ denoting the month election is held, and $\left[\operatorname{elec}_{t-1}{ }_{-} 2=(12-\mathrm{x}) / 12\right]$ is allocated to the year before the election (if pre-election years overlap, elec_2 can exceed 1). Hence, this indicator allows us to directly control for fluctuations in election dates across as well as within countries. It is worth noting that we only include legislative elections for countries with parliamentary political systems and presidential elections for countries with presidential systems. Elections dates are taken from "Comparative Political Data Set I" [Armigneon et al. (2008)]. These data where complemented, when needed, by "Inter-Parliamentary Union" database. 


\subsection{Empirical Specification}

Following the relevant literature we apply the Fixed Effects model specification [see among others Brender and Drazen (2005), Persson and Tabellini (2003) and Schuknecht (2000)]. Hence, our empirical model is of the following form:

$$
Y_{i t}=a_{0} Y_{i t-1}+a_{1} e l e c+\beta \mathrm{Z}+\mu_{i}+\lambda_{i}+\varepsilon_{i t}
$$

where $\mathrm{Y}_{\mathrm{it}}$ is a fiscal indicator in country $i$ in year $t$, elec is the indicator we use to capture the influence of elections and $\mathrm{Z}$ is the vector of country-specific and time-varying socioeconomic variables we hold constant. In addition, $\mu_{\mathrm{i}}$ and $\lambda_{\mathrm{i}}$ are country and time-specific fixed effects and $\varepsilon_{\mathrm{it}}$ is the error term. Time fixed effects, as can be seen by the F-test results presented in the Tables, are in general significant and therefore there are included in regressions. ${ }^{9}$

Given that fiscal instruments display a great deal of persistence, we include the lagged dependent variable $\mathrm{Y}_{\mathrm{it}-1}$ on the right hand side of the estimated equation. The lagged dependent variable is utilized as a means of capturing the dynamics of politics. There are theories in which an attitude at time $t$ is a function of that same attitude at $t-1$ as modified by new information. Apart from the theory, the inclusion of a lagged dependent variable often eliminates serial correlation of errors. However, including a lagged dependent variable, introduces a potential bias by not satisfying the strict exogeneity assumption of the error term $\varepsilon_{i t}$. Still, as it is analyzed in the literature, the estimated bias of this formulation is of order $1 / \mathrm{T}$, where $\mathrm{T}$ is the length panel, even as the number of countries becomes large [see among others Nickell (1981), Kiviet (1995), Wooldridge (2002)]. The average time series length of our panel depends on the fiscal indicator we use, but in general is above 24 years and the bias is probably negligible. In addition, as suggested by Roodman (2006), when employing a system/difference GMM estimator the number of instruments should be less than or equal to the number of cross sections. An excessive number of instruments can result in an over fitting of the instrumented variables, thereby biasing the results towards those of the OLS estimator.

\footnotetext{
${ }^{9}$ The qualitative results in all regressions do not significantly change when we exclude year effects.
} 
Moreover, our model is tested by performing a modified Wald statistic for groupwise heteroskedasticity, as proposed by Green (2000), of the null hypothesis of homoscedasticity versus the alternative hypothesis of heteroskedasticity across groups. The null hypothesis cannot be accepted, indicating the presence of groupwise heteroskedasticity. Therefore, in our estimation procedure we use Huber-White standard errors to correct for groupwise heteroskedasticity.

\subsection{Results}

In this section we first present evidence from estimating equation (18) for various fiscal variables using elec as the pre-electoral indicator. We then address the potential endogeneity of electoral procedures by separating out those elections whose timing is predetermined. Finally, we look how our results are affected by using elec_2 as an alternative pre-electoral indicator.

\subsubsection{Basic Results}

Table 1 shows the results when we include in our regressions binary indicator elec. Regarding the socio-economic variables, the coefficient of $\operatorname{lgdppc}$ is insignificant for all regressions, while growth is negative when statistically significant except for the case of fiscal variable indirect_rev. In the next section we will include in our regressions alternative socio-economic variables, as proposed by Persson and Tabellini (2003), in order to show that our results are not driven by the inclusion of specific control variables.

To continue with, as far as aggregate fiscal data are concerned, we find no evidence for an electoral cycle for government deficit and expenditures as shown by the statistical insignificance of elec in columns (1) and (2). These findings are corroborated by the stylized facts presented in the studies of Brender and Drazen (2005) and Shi and Svensson (2006), in which fiscal cycles are driven by the experience of "new" democracies and less developed countries. Second, in accordance with the results of Brender and Drazen (2005), Persson and Tabellini (2003, chapter 8), we find a significant government revenues cycle, which reveals that in developed/established democracies government revenues fall during an election year. 
By looking at decomposed fiscal data we see that elections seem to have a negative and statistically significant effect on capital in column (4) and a statistically insignificant effect on current in column (5). Turning now to the effect of tax variables, direct seems to decrease before election, while indirect does not seem to be affected by the election period. These results indicate that direct taxation seems to be the driving force of the government revenues cycle.

Next, at columns (8) to (11) of Table 1 we test if elections affect the composition of total expenditures and revenues. The results are consistent with our previous findings of a fall in government investment before elections. One can see in column (8) that elections decrease capital expenditures as a percentage of total expenditures. This implies that current expenditures, as a ratio of total spending should rise. Indeed the coefficient of elec in column (9) is positive and statistically significant revealing that current_exp is expanded in election year. This result is similar to those obtained by Block (2002) and Vergne (2009), but for a sample of new democracies and developing countries rather than a sample of established/developed democracies as in our case. At the same time, it is worth noticing, that the magnitude of fiscal manipulation seems much pronounced in these former studies. In addition, regarding pre-electoral tax composition only variable direct_rev seems to decrease in the election year.

Table 1 here

These results are consistent with Rogoff's (1990) notion that ego rents from staying in office and information asymmetry induce incumbents to manipulate fiscal policy towards more visible public goods. What we see when fiscal elements are scaled to GDP is that government tries to "signal" its competence by decreasing visible government revenues, and more particularly direct taxation, in order to provide immediate economic benefit to voters. On the other hand, capital expenditures, which may only be observed by voters with a lag, seem to decrease in election year. As far as the composition of expenditures is concerned, we observe that public spending shifts towards more visible current expenditures and away from capital expenditures. The fact that we do not observe a PBC confirms the view that these cycles are driven by the 
experience of "new" democracies and less developed countries where information asymmetries are more pronounced. In the case of developed countries, incumbents are more cautious when manipulating fiscal policy, because hi-tech media and advanced accounting practices allow well-informed voters to evaluate more precisely a government's performance (competence). Furthermore, some studies support the view that voters seem to be fiscal conservatives and punish rather than reward loose fiscal policies during election year [see among others Peltzman (1992) and Brender and Drazen (2008)]. This is probably the reason why incumbents on the one hand decrease taxation, while on the other hand balance the fiscal budget by decreasing public investment.

\subsubsection{Predetermined election dates}

Another interesting issue concerning this literature is that election dates may not be exogenous. As argued by Rogoff (1990), when elections are held at the end of the term, distortions on the shape of fiscal policy can be more severe. The main reason is that incompetent incumbents may prefer to wait until the end of the term in order to receive additional ego rents from staying in office. At the same time, when election date is known in advance, opportunistic incumbent has ample to use fiscal policy in order to increase re-election probabilities, far greater, compared to the case of elections being called earlier. On the other hand, according to Berument and Heckelman (1998), incumbents probably are tempted to call early election, when economic conditions are particularly favorable, as an attempt to affect voting behavior, while incumbents without this option can only rely on fiscal manipulation. One way to address this issue, based on Brender and Drazen (2005) approach, is to separate out those elections whose timing is predetermined. We define as predetermined those elections, which are held either at the fixed interval or during the expected year of the constitutionally fixed term. Hence, we separate binary indicator elec into variables elec_pred and elec_end, for predetermined and endogenous election dates, respectively. In our case, among the 125 elections in the sample, 64 elections are classified as predetermined.

As can be seen at Table 2, the basic findings for variable elec can be attributed to elections being held at the predetermined date. More specifically, we find that the coefficient of the electoral variable elec_pred reveals a government revenues cycle in 
election year, similar to what was found by Brender and Drazen (2005) for a sample of established democracies. Also, as before, government revenues cycle is driven by a fall in direct taxation. At the same time, public investment seems to deteriorate during preelectoral period, which may be lying behind the finding of a neutral fiscal balance cycle. In addition, we find a shift towards more visible current expenditures share and away from capital expenditures. Regarding endogenously chosen electoral procedures, the coefficient on elec_end reveals a fiscal balance cycle at the $10 \%$ level of significance. Hence, although the magnitude of pre-electoral distortions seems subtle for endogenously chosen elections, we have indications showing manipulation of the fiscal balance.

Table 2 here

\subsubsection{Weighted electoral indicators}

Moving one step forward, in Table 3, we use the alternative electoral indicators elec $_{t} 2$ and $e l e c_{t-1}{ }_{2}$ that take into account the exact timing of elections. Thus, we proceed into a four-way split. More precisely, we split indicator $e l e c \_2$ into $e l e c_{t} \_$pred_2 (elect_end_2) and $e l e c_{t-1} \_$pred_2 ( $e l e c_{t-1}$ end_2), for predetermined (endogenous) election and preelection years, respectively. Regarding the case of predetermined elections one can draw two main conclusions from Table 3. Firstly, all electoral effects are captured by elect_pred_2, while in all cases the coefficients of variable elec $_{t-1} \_$pred_2 all are insignificantly related with fiscal variables. This finding indicates that electoral manipulation of fiscal policy occurs close to the election date. Secondly, the impact of elec t_pred_2 $_{2}$ on fiscal variables supports our previous results of a pre-electoral decrease in total revenue attributed to a fall in direct taxation as well as a fall in capital expenditures reflected to a shift of the composition of public spending towards more visible current expenditures and away from capital expenditures.

Our basic findings in Table 1 and Table 2, which are consistent with the rest of the literature, support the view that dummy variable elec, which does not take into account the exact timing of elections, captures the influence of elections on fiscal policy equally well with the more precise electoral indicator elec_2. 
For endogenous elections dates, results reveal a rise in revenue in the "early" preelection period captured by $e l e c_{t-1}$ end_2 triggered by a rise in direct revenues as a percentage of GDP. This revenue cycle is then followed with a significant fiscal balance cycle that is driven by an increase in current expenditures immediately before elections as shown by the coefficient of $e l e c_{\text {t_end_2. }}$. One possible explanation is that incumbents may call for elections prematurely when fiscal condition is favorable because the rise in revenue and budget surplus provides them a "leeway" for pre-electoral spending.

Table 3 here

These findings suggest a different behavior on behalf of the incumbent, which depends on the timing of elections. In particular, for predetermined elections an incumbent has the opportunity to shape fiscal policy far greater, than if early elections are held. Hence, opportunistic incumbents provide immediate benefits to voters by decreasing direct taxation, while public investment seems to deteriorate so that fiscal balance remains unaffected. On the other hand, early and unexpected elections and short campaign periods may induce incumbent to react abruptly and engage in expansionary fiscal policy even though it may has counter effects if it is perceived by voters as electoral manipulation.

To sum up, our results for competitive elections in high-income OECD countries and "old" democracies reveal that incumbents manipulate fiscal policy in order to stay in office. One reason behind this result is that multi-party elections and uncertainty for the outcome induce incumbents to manipulate fiscal policy instruments. On the other hand, voters at developed counties are well informed regarding the level of distortions an incumbent tries to induce in fiscal policy during election year, as well as about its level of competence. Our findings tend to reveal that incumbents seem to cautiously manipulate fiscal policy instruments. This inference is supported by the magnitude of fiscal policy manipulation in our sample, which seems much smaller in comparison with similar studies for "new" democracies and developing countries according to Block (2002) and Vergne (2009). 


\subsection{Sensitivity analysis}

In this section we examine the robustness of the above results by re-estimating the regressions under various modifications. Firstly, we re-estimate our baseline specification using alternative control variables as proposed by Persson and Tabellini (2003). Secondly, we use an alternative way of specifying a dynamic model via the error term rather than using a lagged dependent variable. Thirdly, we apply the method developed by Hadi (1992) in order to identify and drop outlier observations from our regressions. Finally, in section 3.4.4. we conduct some additional empirical checks to ensure that our findings are robust. In order to save some space, we present analytical results only for our basic election dummy elec, while for specifications in Tables 2 and 3 we present results only for the electoral indicators. ${ }^{10}$

\subsubsection{Alternative control variables}

Until now we have applied in our baseline regressions time varying socio-economic variables as proposed by Shi and Svensson (2006). In order to test if our results are driven by this specification, we introduce in our estimated equation some alternative control variables as proposed by Persson and Tabellini (2003). In particular, we use the $\log$ of real per capita GDP $(\lg d p p c)$, since, according to Wagner's law, we expect that richer countries should have bigger public sectors. Moreover, we use output gap ( $g d p h p)$ to control for fluctuations in fiscal policy induced by the business cycle and defined as the log difference between real GDP and its country specific trend computed using Hodrick-Prescott filter. Furthermore, we use two demographic variables representing the percentage of population aged 15-64 (pop1564), and above 65 years of age (pop65+), as demographic evolution may put pressure on the public budget. Finally, we use the degree of a country's openness to trade (trade), since according to Rodrick's (1998) proposition more open economies are expected to have bigger public sectors as a safety net against the exposure to the terms of trade risk. All macroeconomic data for control variables are expressed as percentages and obtained from World Bank's "World Development Indicators" (WDI).

\footnotetext{
${ }^{10}$ Results available upon request.
} 
Regarding the socio-economic variables, we observe that the coefficient of $\lg d p p c$ is insignificant, while gdphp is positive when statistically significant. The two demographic variables, pop1564 and pop65+, except for the case of fiscal variable indirect_rev, are positive when statistically significant. Moreover, trade doesn't seem to verify Rodrick's (1998) proposition, because results reveal, in most of the cases, a negative relation between fiscal variables and country openness to trade. Hence, results generally do not seem to confirm theoretical predictions.

Table 4A and 5A here

As for the electoral effects, apart from some negligible changes in significance levels, as can be seen in Tables 4A and 5A qualitative results remain essentially the same to those depicted in Tables 1-3. More specifically, we obtain a significant government revenues cycle, a fall in public investment and a shift in spending composition towards more visible public goods.

\subsubsection{Regression in First Differences}

Although our results reveal coefficients less than one for the lagged dependent variable, we want to assure that the time path is stationary. To the best of our knowledge, Maddala and $\mathrm{Wu}(1999)$ unit root test is the only test available for a time series cross-section data set with an unbalanced panel. However, a shortcoming of this test is that it is constructed from averaging the p-values for any test from each cross-sectional unit. Conventional panel unit root tests are sensitive to the existence of a few stationary series that may lead to the false rejection of the joint unit root hypothesis (see Taylor and Sarno (1998)). For this reason, we check if our estimates are affected by unit root by applying the method of Levitt (1997). In particular, we are first differencing our dependent variable and all covariates of our model with the exception of election indicator variables. This implies that we put more structure on the data for the identification of the election effect. Additionally, the first difference of lagged dependent variable was generally insignificant and was dropped from the estimated equation. Also, taking first differences due to stationarity reasons eliminates time-invariant fixed effects. But there could also be 
time fixed effects in each country, so that first differencing just eliminates the timeinvariant country effects, but not the time fixed effects. As can be seen in Table 4B, time fixed effects are in general significant and are included in regressions. Thus, the estimated equation has the following form:

$$
\Delta \mathrm{Y}_{i t}=a_{1} \text { elec }+\beta \Delta \mathrm{Z}+\lambda_{i}+\varepsilon_{i t}
$$

Turning to the results, our findings in Tables $4 \mathrm{~B}$ and $5 \mathrm{~B}$ remain similar to those depicted in Tables 1-3. At the same time, one minor difference in results is that the coefficient of elec $_{t}$ end in Table 5B, in comparison with results in Table 2, turns out to be significantly and positively related with variable current_exp.

Table 4B and 5B here

\subsubsection{Testing for outliers}

As a next step, in order to further increase the precision of our results and ensure that extreme values do not drive them, we use the Hadi (1992) method that identifies multiple outliers in multivariate data. This method measures the distance of data points from the main body of data and then iteratively reduces the sample to exclude distant data points. ${ }^{11}$

Hadi's (1992) approach identifies 6, 10 and 13 outlier observations for fiscal variables capital, capital_exp and current_exp, respectively. At Tables 4C and 5C we reestimate our regressions after dropping the identified outlier observations. As can be seen, results regarding all electoral indicators remain unaffected in comparison with results depicted in Tables 1-3.

Table 4C and 5C here

\footnotetext{
${ }^{11}$ We set the significance level for outlier cutoff at $\mathrm{p}=0.1$.
} 


\subsubsection{Some additional checks}

We also conduct some additional checks to ensure that our findings are not product of particular samples or specifications. First, as mentioned above, we excluded Greece, Portugal and Spain from the sample, since we have doubts about the persistence of the "new democracy" effect. Alternatively, however, following Brender and Drazen (2005), we re-estimate equation (18) including all developed countries in the sample, but we exclude the first four competitive elections that took place in Greece, Portugal and Spain. The qualitative results derived are similar to the initial sample of established democracies.

Second, as outlined by Persson and Tabellini (2003), pre-electoral manipulation in fiscal policy may depend significantly on the nature of the political system. More specifically, electoral cycles may differ between proportional and majoritarian systems or presidential and parliamentary governments. Regarding the first classification, 14 countries in our sample use proportional voting rules while 5 countries use majoritarian rules. Our results, suggest that our findings for the sample of 19 "old" democracies are very much alike with those depicted for countries that use proportional rules. This result seems to verify the notion that the fall in government investment is indeed a more expected result in a proportional system. Politicians in this system are more prone to cut geographically targeted public spending such as investment rather than transfers which are easier to target across social groups [see Milesi-Ferreti et al. (2002), Persson and Tabellini (2000)]. Concerning the second part of constitutional rules, we have only two presidential democracies, Switzerland and the U.S.A.. It should be noted that qualitative results remain unaffected after dropping Switzerland and the U.S.A. from our sample.

Finally, one last check is to exclude from sample years 1993 to 1999, in order to investigate whether the Stability and Growth Pact $(S G P)$ agreement had any effect on the adoption of fiscal policy by the members of the European Union and consequently on our results. ${ }^{12}$ Apart from some negligible changes, all results remain unaffected. ${ }^{13}$

\footnotetext{
12 The SGP agreement is based on articles 99 and 104 of the European Community Treaty that adopted at 1993 in Maastricht. The actual criteria that member states must respect are: (i) an annual budget deficit no higher than $3 \%$ of GDP, (ii) a natioanl debt lower than $60 \%$ of GDP or approaching that value.

${ }^{13}$ Results for these modifications are available upon request.
} 


\section{Conclusions}

Electoral incentives can affect both the level and the composition of fiscal policy. Office motivated incumbent policymakers may shift public expenditure towards more visible current expenditure and away from less visible capital expenditure in order to improve the voters' perception of their ability thereby increasing the probability of being reelected. This paper presented empirical results for a sample of 19 developed, established democracies over the period 1972-1999 that support this theoretical prediction. Indeed we find robust evidence that indicate that elections decrease capital and increase current expenditures as a percentage of total expenditures.

Regarding aggregate fiscal variables, in line with Brender and Drazen (2005) and Shi and Svensson (2006) we find no evidence for an electoral cycle for government deficit and expenditures but we do find a negative effect of election on revenue. Going a step further, we look at the electoral impact on the composition of fiscal revenue and find that the fall in revenue in election periods is attributed to a fall in direct taxation. This implies that policymakers prefer to cut the part of taxation that is more visible to voters since it has a direct impact on their disposable income. Moreover, a cut in direct taxation is likely to have a positive impact on growth by affecting individuals' savings and labour supply decisions. Finally, attempting to distinguish between pre-determined and endogenous elections reveals that - in line with the assumptions of the theoretical model- both the revenue cycle and the shift in the composition of public expenditure occur when elections are exogenous. 


\section{REFERENCES}

Alesina, A., Roubini, N., Cohen G., (1997): Political Cycles and the Macroeconomy, Cambridge, MA: MIT Press.

Angelopoulos K., Economides G., (2008): Fiscal Policy, Rent Seeking and Growth under Electoral Uncertainty Theory and Evidence from the OECD, Canadian Journal of Economics, 41:4, 1375--1405.

Armingeon K., Gerber M., Leimgruber P., Beyeler M., (2008): The Comparative Political Data Set 1960-2006 for 23 OECD Countries.

http://www.ipw.unibe.ch/content/team/klaus_armingeon/comparative_political_data_sets $\underline{\text { index_ger.html }}$

Baum, C., (2001): “XTTEST3": Stata module to compute Modified Wald statistic for groupwise heteroskedasticity, http://ideas.repec.org/c/boc/bocode/s414801.html

Berument, H., Heckelman J., (1998): Political Business Cycles and Endogenous Elections, Southern Economic Journal, 64:4, 987--1000.

Besley, T., Case A., (1995): Does Political Accountability Affect Economic Policy Choices?, Quarterly Journal of Economics, 110:3, 769--798.

Block, S., (2002): Elections, Electoral Competitiveness, and Political Budget Cycles in Developing Countries, Harvard University CID Working Paper No. 78.

Brender, A., Drazen A., (2005): Political Budget Cycles in New versus Established Democracies, Journal of Monetary Economics, 52:7, 1271--1295.

Brender, A. Drazen A., (2008): How Do Budget Deficits and Economic Growth Affect Reelection Prospects? Evidence from a Large Panel of Countries, American Economic Review, 98:5, 2203--20.

Cukierman, A., Meltzer A., (1986): A Positive Theory of Discretionary Policy, the Cost of Democratic Government, and the Benefits of a Constitution, Economic Inquiry 24:3, 367--88.

Drazen, A., (2000): The Political Business Cycle After 25 Years, NBER Macroeconomic Annual, Cambridge, MA: MIT Press.

Franzese, R., (2000): Electoral and Partisan Manipulation of Public Debt in Developed Democracies, 1956-1990, in Ralph Strauch, Jürgen von Hagen (eds), Institutions, Politics and Fiscal Policy, 61--83. Dordrecht: Kluwer Academic Press.

Global Development Network Growth Database, http://dri.fas.nyu.edu/object/dri.resources.growthdatabase 
Greene, W., (2000): Econometric Analysis. $3^{\text {rd }}$ ed., Upper Saddle River, NJ: PrenticeHall.

Hadi, A., (1992): Identifying multiple outliers in multivariate data, Journal of the Royal Statistical Society, Series B, 54:3, 761--771.

Inter-Parliamentary Union database, http://www.ipu.org/english/home.htm

Kiviet, J., (1995): On bias, inconsistency, and efficiency of various estimators in dynamic panel data models, Journal of Econometrics, 68:1, 53--78.

Kneller, R., Bleaney, M., Gemmell, N., (1999): Fiscal policy and growth: evidence from OECD countries, Journal of Public Economics, 74:2, 171--190.

Levitt, S., (1997): Using Electoral Cycles in Police Hiring to Estimate the Effect of Police on Crime, American Economic Review, 87:3, 270--290.

Lindbeck, A., (1976): Stabilization Policies in Open Economies with Endogenous Politicians, American Economic Review, 66:2, 1--19.

Maddala, S., Wu, S., (1999): A Comparative Study of Unit Root Tests with Panel Data and a New Simple Test, Oxford Bulletin of Economics and Statistics, 61:0, 631--652.

Malley, J., Philippopoulos, A., Woitek, U., 2007: Electoral uncertainty, fiscal policy and macroeconomic fluctuations, Journal of Economic Dynamics and Control, 31:3, 1051-1080 .

Milesi-Ferretti, G., Perotti, R., Massimo, R., (2002): Electoral Systems And Public Spending, The Quarterly Journal of Economics, 117:2, 609--657.

Mink, M., de Haan J., (2005): Has the Stability and Growth Pact Impeded Political Budget Cycles in the European Union?, CESifo Working Paper No. 1532.

Nickell, S., (1981): Biases in dynamic models with fixed effects, Econometrica, 49:6, 1417--1426.

Nordhaus, W., (1975): The Political Business Cycle, Review of Economic Studies, 42:2, 169--90.

OECD (2006): Macroeconomic effects of a shift from direct to indirect taxation: A simulation for 15 EU Member States. Note presented by the European Commission at the 72nd meeting of the OECD Working Party No. 2 on Tax Policy Analysis and Tax Statistics.

Persson, T., Tabellini G., (1990): Macroeconomic Policy, Credibility and Politics, Harwood Academic Publishers, New York. 
Persson, T., Tabellini G., (2003): The Economic effect of constitutions, Cambridge, MA: MIT Press.

Persson, T., Tabellini G., (2000): Political Economics: Explaining economic policy, Cambridge, MA: MIT Press.

Rodrik D., (1998): Why do more open economies have bigger governments?, Journal of Political Economy, 106:5, 997--1032.

Rogoff, K., (1990): Equilibrium Political Budget Cycles, American Economic Review, $80: 1,21--36$.

Rogoff, K., Sibert A., (1988): Elections and Macroeconomic Policy Cycles, Review of Economic Studies, 55:1, 1--16.

Roodman, D., (2006): How to do xtabond2: an introduction to "Difference" and "System" GMM in Stata, Center for Global Development Working Paper No. 103.

Saporiti, A., Streb J., (2008): Separation of Powers and Political Budget Cycles, Public Choice, 137:1, 329--345.

Schuknecht, L., (1996): Political Business Cycles and Fiscal Policies in Developing Countries, Kyklos, 49:2, 155--170.

Schuknecht, L., (2000): Fiscal Policy Cycles and Public Expenditure in Developing Countries, Public Choice 102:1-2, 115--130.

Shi, M., Svensson J., (2006): Political budget cycles: Do they differ across countries and why?, Journal of Public Economics, 90:8-9, 1367--1389.

Taylor, M., Sarno, L., (1998): The behavior of real exchange rate during the post- Bretton Woods period, Journal of International Economics, 46:2, 281--312.

Tufte, E., (1978): Political Control of the Economy, Princeton: Princeton University Press.

Vergne, C., (2009): Democracy, Elections and Allocation of Public Expenditures in Developing Countries, European Journal of Political Economy, 25:1, 63--77.

Wooldridge, J., (2002): Econometric Analysis of Cross Section and Panel Data, Cambridge, MA: MIT Press.

World Bank, World Bank Developments Indicators, http://ddpext.worldbank.org/ext/DDPQQ/member.do?method=getMembers\&userid=1\&q $\underline{\text { ueryId }=6}$ 


\begin{tabular}{|c|c|c|c|c|c|c|c|}
\hline Variable & Description & Obs. & Mean & Std.dev. & Min & Max & Source \\
\hline balance & Surplus/deficit as a share of GDP (\%) & 490 & -3.290 & 3.899 & -16.171 & 9.354 & Global Development Network Growth Database \\
\hline expenditures & Total expenditures as a share of GDP (\%) & 495 & 35.228 & 10.241 & 12.126 & 58.706 & Global Development Network Growth Database \\
\hline revenues & Total revenues as a share of GDP (\%) & 495 & 32.692 & 9.556 & 9.586 & 52.517 & Global Development Network Growth Database \\
\hline capital & Capital expenditures as a share of GDP (\%) & 486 & 2.534 & 1.298 & 0.242 & 7.685 & Global Development Network Growth Database \\
\hline capital_exp & $\begin{array}{l}\text { Capital expenditures as a share of total expenditures } \\
(\%)\end{array}$ & 486 & 7.503 & 4.138 & 1.186 & 26.101 & $\begin{array}{l}\text { Own calculations, data taken from Global } \\
\text { Development Network Growth Database }\end{array}$ \\
\hline current & Current expenditures as a share of GDP (\%) & 486 & 32.716 & 9.822 & 9.015 & 54.186 & Global Development Network Growth Database \\
\hline current_exp & $\begin{array}{l}\text { Current expenditures as a share of total expenditures } \\
(\%)\end{array}$ & 486 & 92.527 & 4.121 & 73.899 & 98.814 & $\begin{array}{l}\text { Own calculations, data taken Global Development } \\
\text { Network Growth Database }\end{array}$ \\
\hline direct & $\begin{array}{l}\text { Sum of taxation on income and profits, social security } \\
\text { contributions, taxation on payroll and manpower and } \\
\text { taxation on property as a share of GDP (\%) }\end{array}$ & 494 & 19.528 & 7.131 & 5.014 & 36.491 & $\begin{array}{l}\text { Own calculations based on Kneller's et al. (1999) } \\
\text { methodology, data taken from Global Development } \\
\text { Network Growth Database }\end{array}$ \\
\hline direct_rev & Sum of direct taxation as a share of total revenues (\%) & 494 & 60.275 & 13.739 & 19.398 & 89.125 & $\begin{array}{l}\text { Own calculations based on Kneller's et al. (1999) } \\
\text { methodology, data taken from Global Development } \\
\text { Network Growth Database }\end{array}$ \\
\hline indirect & $\begin{array}{l}\text { Taxation on domestic goods and services as a share of } \\
\text { GDP }(\%)\end{array}$ & 501 & 9.287 & 4.284 & 0.607 & 17.787 & Global Development Network Growth Database \\
\hline indirect_rev & $\begin{array}{l}\text { Taxation on domestic goods and services as a share of } \\
\text { total revenues }(\%)\end{array}$ & 494 & 27.775 & 10.684 & 3.126 & 51.505 & $\begin{array}{l}\text { Own calculations, data taken Global Development } \\
\text { Network Growth Database }\end{array}$ \\
\hline lgdppc & The log of real per capita income. & 551 & 9.887 & 0.033 & 8.958 & 10.742 & World Bank Development indicators \\
\hline growth & Per capita growth rate of output (\%) & 551 & 2.971 & 2.407 & -7.283 & 11.680 & World Bank Development indicators \\
\hline gdphp & $\begin{array}{l}\text { Difference between the natural log of real GDP in the } \\
\text { country and its country-specific trend (obtained, using } \\
\text { the Hodrick-Prescott filter). }\end{array}$ & 551 & -0.034 & 2.294 & -7.913 & 8.523 & World Bank Development indicators \\
\hline pop1564 & $\begin{array}{l}\text { Population between } 15 \text { and } 64 \text { years old as a share of } \\
\text { total population. (\%) }\end{array}$ & 551 & 65.779 & 2.392 & 57.648 & 69.768 & World Bank Development indicators \\
\hline pop65+ & $\begin{array}{l}\text { Population over the age of } 65 \text { as a share of total } \\
\text { population. (\%) }\end{array}$ & 551 & 13.286 & 2.285 & 7.376 & 18.212 & World Bank Development indicators \\
\hline
\end{tabular}



lections not held in the expected year and 0 otherwise.

elect $\_$pred_2

Indicator variable that receives value $(\mathrm{x} / 12)$ in the

elect $t$-1_pred_2

ator variable that receives value (1-

elect $t_{t}$ pred_2) in the election year, with $x$ the months before election, when elections held in the

predetermined date and 0 otherwise.

elect $\_$end_2

Indicator variable that receives value $(\mathrm{x} / 12)$ in the election year, with $\mathrm{x}$ the months before election, when elections not held in the predetermined date and 0 otherwise.

elect $t_{t-1}$ end_2

Indicator variable that receives value (1elect $t_{-}$end_2) in the election year, with $x$ the months before election, when elections not held in the predetermined date and 0 otherwise. 
"Table 1. Elections and fiscal policy: basic findings"

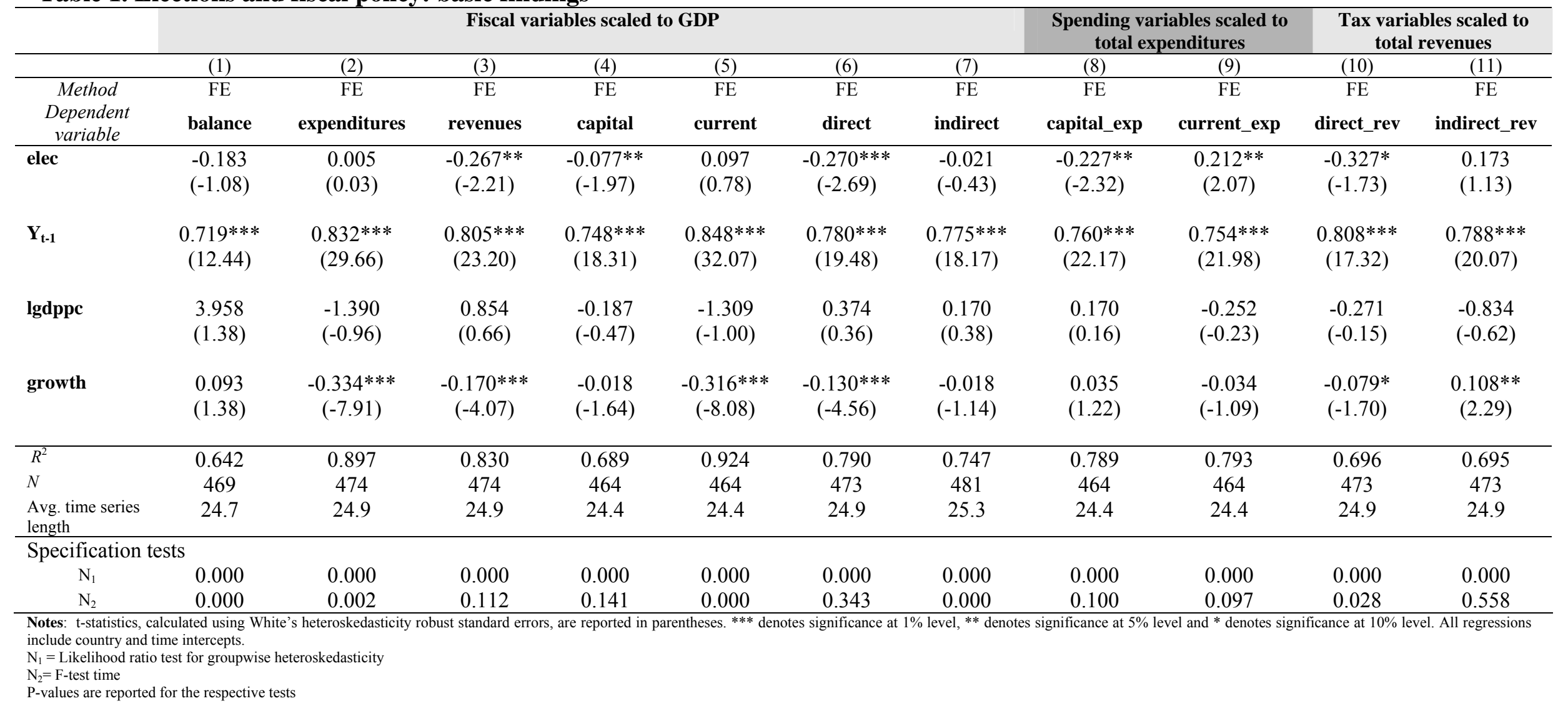


“Table 2. Predetermined vs. Endogenous elections"

\begin{tabular}{|c|c|c|c|c|c|c|c|c|c|c|c|}
\hline & \multicolumn{7}{|c|}{ Fiscal variables scaled to GDP } & \multicolumn{2}{|c|}{$\begin{array}{c}\text { Spending variables scaled to } \\
\text { total expenditures }\end{array}$} & \multicolumn{2}{|c|}{$\begin{array}{c}\text { Tax variables scaled to total } \\
\text { revenues }\end{array}$} \\
\hline & (1) & (2) & (3) & (4) & (5) & (6) & (7) & (8) & (9) & $(10)$ & $(11)$ \\
\hline $\begin{array}{c}\text { Method } \\
\text { Dependent } \\
\text { variable }\end{array}$ & $\begin{array}{c}\mathrm{FE} \\
\text { balance }\end{array}$ & $\begin{array}{c}\mathrm{FE} \\
\text { expenditures }\end{array}$ & $\begin{array}{c}\mathrm{FE} \\
\text { revenues }\end{array}$ & $\begin{array}{c}\text { FE } \\
\text { capital }\end{array}$ & $\begin{array}{c}\text { FE } \\
\text { current }\end{array}$ & $\begin{array}{c}\mathrm{FE} \\
\text { direct }\end{array}$ & $\begin{array}{c}\mathrm{FE} \\
\text { indirect }\end{array}$ & $\begin{array}{c}\text { FE } \\
\text { capital_exp }\end{array}$ & $\begin{array}{c}\text { FE } \\
\text { current_exp }\end{array}$ & $\begin{array}{c}\mathrm{FE} \\
\text { direct_rev }\end{array}$ & $\begin{array}{c}\text { FE } \\
\text { indirect_rev }\end{array}$ \\
\hline elec_pred & $\begin{array}{l}-0.027 \\
(-0.12)\end{array}$ & $\begin{array}{l}-0.153 \\
(-1.06)\end{array}$ & $\begin{array}{c}-0.345 * * \\
(-2.58)\end{array}$ & $\begin{array}{c}-0.112 * * \\
(-2.38)\end{array}$ & $\begin{array}{l}-0.024 \\
(-0.19)\end{array}$ & $\begin{array}{c}-0.346 * * * \\
(-2.94)\end{array}$ & $\begin{array}{l}-0.010 \\
(-0.17)\end{array}$ & $\begin{array}{c}-0.288 * * \\
(-2.48)\end{array}$ & $\begin{array}{c}0.247 * * \\
(1.98)\end{array}$ & $\begin{array}{l}-0.388^{*} \\
(-1.80)\end{array}$ & $\begin{array}{l}0.264 \\
(1.44)\end{array}$ \\
\hline elec_end & $\begin{array}{c}-0.426^{*} \\
(-1.96)\end{array}$ & $\begin{array}{l}0.248 \\
(1.01)\end{array}$ & $\begin{array}{l}-0.146 \\
(-0.79)\end{array}$ & $\begin{array}{l}-0.021 \\
(-0.36)\end{array}$ & $\begin{array}{l}0.292 \\
(1.31)\end{array}$ & $\begin{array}{l}-0.153 \\
(-1.07)\end{array}$ & $\begin{array}{l}-0.039 \\
(-0.53)\end{array}$ & $\begin{array}{l}-0.129 \\
(-0.92)\end{array}$ & $\begin{array}{l}0.157 \\
(1.12)\end{array}$ & $\begin{array}{l}-0.232 \\
(-0.75)\end{array}$ & $\begin{array}{l}0.032 \\
(0.13)\end{array}$ \\
\hline $\mathbf{Y}_{\mathrm{t}-\mathbf{1}}$ & $\begin{array}{c}0.719 * * * \\
(12.36)\end{array}$ & $\begin{array}{c}0.831 * * * \\
(29.90)\end{array}$ & $\begin{array}{c}0.804 * * * \\
(23.21)\end{array}$ & $\begin{array}{c}0.746^{* * *} \\
(18.53)\end{array}$ & $\begin{array}{c}0.847 * * * \\
(32.13)\end{array}$ & $\begin{array}{c}0.779 * * * \\
(19.50)\end{array}$ & $\begin{array}{c}0.774 * * * \\
(18.12)\end{array}$ & $\begin{array}{c}0.759 * * * \\
(22.09)\end{array}$ & $\begin{array}{c}0.753 * * * \\
(21.84)\end{array}$ & $\begin{array}{c}0.807 * * * \\
(17.29)\end{array}$ & $\begin{array}{c}0.786 * * * \\
(19.86)\end{array}$ \\
\hline lgdppc & $\begin{array}{l}3.911 \\
(1.35)\end{array}$ & $\begin{array}{l}-1.375 \\
(-0.95)\end{array}$ & $\begin{array}{l}0.868 \\
(0.67)\end{array}$ & $\begin{array}{l}-0.174 \\
(-0.43)\end{array}$ & $\begin{array}{l}-1.263 \\
(-0.96)\end{array}$ & $\begin{array}{l}0.387 \\
(0.37)\end{array}$ & $\begin{array}{l}0.168 \\
(0.37)\end{array}$ & $\begin{array}{l}0.200 \\
(0.19)\end{array}$ & $\begin{array}{l}-0.270 \\
(-0.25)\end{array}$ & $\begin{array}{l}-0.258 \\
(-0.14)\end{array}$ & $\begin{array}{l}-0.851 \\
(-0.63)\end{array}$ \\
\hline growth & $\begin{array}{l}0.093 \\
(1.39)\end{array}$ & $\begin{array}{c}-0.335 * * * \\
(-7.96)\end{array}$ & $\begin{array}{c}-0.171 * * * \\
(-4.10)\end{array}$ & $\begin{array}{c}-0.018^{*} \\
(-1.66)\end{array}$ & $\begin{array}{c}-0.316^{* * *} \\
(-8.13)\end{array}$ & $\begin{array}{c}-0.130 * * * \\
(-4.59)\end{array}$ & $\begin{array}{l}-0.018 \\
(-1.13)\end{array}$ & $\begin{array}{l}0.034 \\
(1.21)\end{array}$ & $\begin{array}{l}-0.034 \\
(-1.08)\end{array}$ & $\begin{array}{c}-0.079 * \\
(-1.71)\end{array}$ & $\begin{array}{c}0.108 * * \\
(2.30)\end{array}$ \\
\hline$\overline{R^{2}}$ & 0.643 & 0.897 & 0.830 & 0.690 & 0.925 & 0.791 & 0.747 & 0.789 & 0.793 & 0.706 & 0.693 \\
\hline$N$ & 469 & 474 & 474 & 464 & 464 & 473 & 464 & 464 & 464 & 473 & 473 \\
\hline $\begin{array}{l}\text { Avg. time series } \\
\text { length }\end{array}$ & 24.7 & 24.9 & 24.9 & 24.4 & 24.4 & 24.9 & 25.3 & 24.4 & 24.4 & 24.9 & 24.9 \\
\hline \multicolumn{12}{|c|}{ Specification tests } \\
\hline $\mathrm{N}_{1}$ & 0.000 & 0.000 & 0.000 & 0.000 & 0.000 & 0.000 & 0.000 & 0.000 & 0.000 & 0.000 & 0.000 \\
\hline $\mathrm{N}_{2}$ & 0.000 & 0.001 & 0.133 & 0.124 & 0.000 & 0.366 & 0.000 & 0.096 & 0.098 & 0.029 & 0.580 \\
\hline
\end{tabular}


“Table 3. Alternative timing of elections and Predetermined vs. Endogenous elections"

\begin{tabular}{|c|c|c|c|c|c|c|c|c|c|c|c|}
\hline & \multicolumn{7}{|c|}{ Fiscal variables scaled to GDP } & \multicolumn{2}{|c|}{$\begin{array}{l}\text { Spending variables scaled } \\
\text { to total expenditures }\end{array}$} & \multicolumn{2}{|c|}{$\begin{array}{c}\text { Tax variables scaled to total } \\
\text { revenues }\end{array}$} \\
\hline & (1) & (2) & (3) & (4) & $(5)$ & (6) & (7) & (8) & (9) & $(10)$ & (11) \\
\hline $\begin{array}{c}\text { Method } \\
\text { Dependent } \\
\text { variable }\end{array}$ & $\begin{array}{c}\mathrm{FE} \\
\text { balance }\end{array}$ & $\begin{array}{c}\mathrm{FE} \\
\text { expenditures }\end{array}$ & $\begin{array}{c}\mathrm{FE} \\
\text { revenues }\end{array}$ & $\begin{array}{c}\text { FE } \\
\text { capital }\end{array}$ & $\begin{array}{c}\text { FE } \\
\text { current }\end{array}$ & $\begin{array}{c}\mathrm{FE} \\
\text { direct }\end{array}$ & $\begin{array}{c}\text { FE } \\
\text { indirect }\end{array}$ & $\begin{array}{c}\text { FE } \\
\text { capital_exp }\end{array}$ & $\begin{array}{c}\text { FE } \\
\text { current_exp }\end{array}$ & $\begin{array}{c}\mathrm{FE} \\
\text { direct_rev }\end{array}$ & $\begin{array}{c}\mathrm{FE} \\
\text { indirect_rev }\end{array}$ \\
\hline elec $\_$_pred_2 & $\begin{array}{l}-0.015 \\
(-0.04)\end{array}$ & $\begin{array}{l}-0.244 \\
(-1.05)\end{array}$ & $\begin{array}{c}-0.424 * * \\
(-2.03)\end{array}$ & $\begin{array}{c}-0.186^{* * *} \\
(-2.73)\end{array}$ & $\begin{array}{l}-0.062 \\
(-0.31)\end{array}$ & $\begin{array}{c}-0.405^{* *} \\
(-2.09)\end{array}$ & $\begin{array}{l}0.024 \\
(0.27)\end{array}$ & $\begin{array}{c}-0.508 * * * \\
(-2.86)\end{array}$ & $\begin{array}{l}0.362^{*} \\
(1.89)\end{array}$ & $\begin{array}{l}-0.358 \\
(-1.03)\end{array}$ & $\begin{array}{l}0.310 \\
(1.12)\end{array}$ \\
\hline 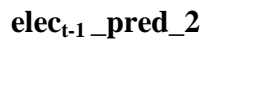 & $\begin{array}{l}-0.258 \\
(-0.68)\end{array}$ & $\begin{array}{l}-0.189 \\
(-0.63)\end{array}$ & $\begin{array}{l}-0.193 \\
(-0.71)\end{array}$ & $\begin{array}{l}-0.064 \\
(-0.66)\end{array}$ & $\begin{array}{l}-0.075 \\
(-0.27)\end{array}$ & $\begin{array}{l}0.105 \\
(0.47)\end{array}$ & $\begin{array}{l}-0.045 \\
(-0.31)\end{array}$ & $\begin{array}{l}-0.298 \\
(-1.12)\end{array}$ & $\begin{array}{l}0.259 \\
(0.93)\end{array}$ & $\begin{array}{l}0.571 \\
(1.24)\end{array}$ & $\begin{array}{l}-0.193 \\
(-0.42)\end{array}$ \\
\hline elec $\mathrm{t} \_$end_2 & $\begin{array}{c}-0.790 * * * \\
(-2.64)\end{array}$ & $\begin{array}{l}0.660^{*} \\
(1.94)\end{array}$ & $\begin{array}{l}0.004 \\
(0.02)\end{array}$ & $\begin{array}{l}0.012 \\
(0.17)\end{array}$ & $\begin{array}{c}0.670^{* *} \\
(2.22)\end{array}$ & $\begin{array}{l}0.024 \\
(0.12)\end{array}$ & $\begin{array}{l}-0.057 \\
(-0.61)\end{array}$ & $\begin{array}{l}-0.139 \\
(-0.77)\end{array}$ & $\begin{array}{l}0.149 \\
(0.82)\end{array}$ & $\begin{array}{l}0.017 \\
(0.04)\end{array}$ & $\begin{array}{l}-0.218 \\
(-0.73)\end{array}$ \\
\hline 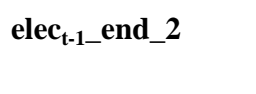 & $\begin{array}{l}0.156 \\
(0.31)\end{array}$ & $\begin{array}{l}0.446 \\
(1.14)\end{array}$ & $\begin{array}{l}0.611^{*} \\
(1.85)\end{array}$ & $\begin{array}{l}0.134 \\
(0.81)\end{array}$ & $\begin{array}{l}0.196 \\
(0.60)\end{array}$ & $\begin{array}{r}0.527^{*} \\
(1.79)\end{array}$ & $\begin{array}{l}-0.204 \\
(-1.36)\end{array}$ & $\begin{array}{l}0.221 \\
(0.48)\end{array}$ & $\begin{array}{l}-0.398 \\
(-0.94)\end{array}$ & $\begin{array}{l}0.426 \\
(0.69)\end{array}$ & $\begin{array}{c}-1.435^{* * *} \\
(-3.35)\end{array}$ \\
\hline $\mathbf{Y}_{\mathbf{t}-1}$ & $\begin{array}{c}0.719 * * * \\
(12.41)\end{array}$ & $\begin{array}{c}0.829 * * * \\
(30.14)\end{array}$ & $\begin{array}{c}0.804^{* * * *} \\
(23.10)\end{array}$ & $\begin{array}{c}0.746^{* * *} \\
(18.50)\end{array}$ & $\begin{array}{c}0.846^{* * *} \\
(32.29)\end{array}$ & $\begin{array}{c}0.778^{* * *} \\
(19.40)\end{array}$ & $\begin{array}{c}0.773^{* * *} \\
(18.07)\end{array}$ & $\begin{array}{c}0.760 * * * \\
(22.23)\end{array}$ & $\begin{array}{c}0.754 * * * \\
(22.01)\end{array}$ & $\begin{array}{c}0.805^{* * *} \\
(17.17)\end{array}$ & $\begin{array}{c}0.783 * * * \\
(20.14)\end{array}$ \\
\hline lgdppc & $\begin{array}{l}3.978 \\
(1.38)\end{array}$ & $\begin{array}{l}-1.476 \\
(-1.02)\end{array}$ & $\begin{array}{l}0.845 \\
(0.65)\end{array}$ & $\begin{array}{l}-0.177 \\
(-0.44)\end{array}$ & $\begin{array}{l}-1.330 \\
(-1.01)\end{array}$ & $\begin{array}{l}0.333 \\
(0.32)\end{array}$ & $\begin{array}{l}0.170 \\
(0.37)\end{array}$ & $\begin{array}{l}0.209 \\
(0.20)\end{array}$ & $\begin{array}{l}-0.290 \\
(-0.27)\end{array}$ & $\begin{array}{l}-0.343 \\
(-0.18)\end{array}$ & $\begin{array}{l}-0.791 \\
(-0.59)\end{array}$ \\
\hline growth & $\begin{array}{l}0.094 \\
(1.39)\end{array}$ & $\begin{array}{c}-0.333 * * * \\
(-7.97)\end{array}$ & $\begin{array}{c}-0.169 * * * \\
(-4.02)\end{array}$ & $\begin{array}{l}-0.017 \\
(-1.60)\end{array}$ & $\begin{array}{c}-0.316^{* * *} \\
(-8.14)\end{array}$ & $\begin{array}{c}-0.130 * * * \\
(-4.51)\end{array}$ & $\begin{array}{l}-0.019 \\
(-1.14)\end{array}$ & $\begin{array}{l}0.036 \\
(1.25)\end{array}$ & $\begin{array}{l}-0.035 \\
(-1.10)\end{array}$ & $\begin{array}{c}-0.080^{*} \\
(-1.71)\end{array}$ & $\begin{array}{c}0.107 * * \\
(2.26)\end{array}$ \\
\hline$R^{2}$ & 0.668 & 0.898 & 0.831 & 0.691 & 0.925 & 0.790 & 0.749 & 0.790 & 0.794 & 0.696 & 0.703 \\
\hline$N$ & 469 & 474 & 474 & 464 & 464 & 473 & 481 & 464 & 464 & 473 & 473 \\
\hline $\begin{array}{l}\text { Avg. time series } \\
\text { length }\end{array}$ & 24.7 & 24.9 & 24.9 & 24.4 & 24.4 & 24.9 & 25.3 & 24.4 & 24.4 & 24.9 & 24.9 \\
\hline Specification tests & & & & & & & & & & & \\
\hline $\mathrm{N}_{1}$ & 0.000 & 0.000 & 0.000 & 0.000 & 0.000 & 0.000 & 0.000 & 0.000 & 0.000 & 0.000 & 0.000 \\
\hline $\mathrm{N}_{2}$ & 0.000 & 0.002 & 0.105 & 0.155 & 0.000 & 0.321 & 0.000 & 0.136 & 0.151 & 0.028 & 0.492 \\
\hline
\end{tabular}


“Table 4A. Robustness: Alternative control variables"

\begin{tabular}{|c|c|c|c|c|c|c|c|c|c|c|c|}
\hline & \multicolumn{6}{|c|}{ Fiscal variables scaled to GDP } & \multicolumn{3}{|c|}{$\begin{array}{l}\text { Spending variables scaled to total } \\
\text { expenditures }\end{array}$} & \multicolumn{2}{|c|}{$\begin{array}{c}\text { Tax variables scaled to total } \\
\text { revenues }\end{array}$} \\
\hline & $(1)$ & $(2)$ & (3) & $(4)$ & $(5)$ & (6) & $(7)$ & $(8)$ & (9) & $(10)$ & $(11)$ \\
\hline $\begin{array}{c}\text { Method } \\
\text { Dependent } \\
\text { variable }\end{array}$ & $\begin{array}{c}\text { FE } \\
\text { balance }\end{array}$ & $\begin{array}{c}\mathrm{FE} \\
\text { expenditures }\end{array}$ & $\begin{array}{c}\mathrm{FE} \\
\text { revenues }\end{array}$ & $\begin{array}{c}\mathrm{FE} \\
\text { capital }\end{array}$ & $\begin{array}{c}\text { FE } \\
\text { current }\end{array}$ & $\begin{array}{c}\mathrm{FE} \\
\text { direct }\end{array}$ & $\begin{array}{c}\text { FE } \\
\text { indirect }\end{array}$ & $\begin{array}{c}\text { FE } \\
\text { capital_exp }\end{array}$ & $\begin{array}{c}\text { FE } \\
\text { current_exp }\end{array}$ & $\begin{array}{c}\text { FE } \\
\text { direct_rev }\end{array}$ & $\begin{array}{c}\text { FE } \\
\text { indirect_rev }\end{array}$ \\
\hline elec & $\begin{array}{l}-0.198 \\
(-1.20)\end{array}$ & $\begin{array}{l}-0.006 \\
(-0.04)\end{array}$ & $\begin{array}{c}-0.289 * * \\
(-2.48)\end{array}$ & $\begin{array}{c}-0.078 * * \\
(-1.99)\end{array}$ & $\begin{array}{l}0.083 \\
(0.60)\end{array}$ & $\begin{array}{c}-0.291 * * * \\
(-2.90)\end{array}$ & $\begin{array}{l}-0.025 \\
(-0.52)\end{array}$ & $\begin{array}{c}-0.224 * * \\
(-2.29)\end{array}$ & $\begin{array}{c}0.205 * * \\
(1.99)\end{array}$ & $\begin{array}{l}-0.334^{*} \\
(-1.75)\end{array}$ & $\begin{array}{l}0.180 \\
(1.17)\end{array}$ \\
\hline $\mathbf{Y}_{\mathrm{t}-\mathbf{1}}$ & $\begin{array}{c}0.682 * * * \\
(12.00)\end{array}$ & $\begin{array}{c}0.836 * * * \\
(25.93)\end{array}$ & $\begin{array}{c}0.789 * * * \\
(22.00)\end{array}$ & $\begin{array}{c}0.744 * * * \\
(17.76)\end{array}$ & $\begin{array}{c}0.854 * * * \\
(27.96)\end{array}$ & $\begin{array}{c}0.773 * * * \\
(19.35)\end{array}$ & $\begin{array}{c}0.782 * * * \\
(18.21)\end{array}$ & $\begin{array}{c}0.753 * * * \\
(21.46)\end{array}$ & $\begin{array}{c}0.744 * * * \\
(20.96)\end{array}$ & $\begin{array}{c}0.798 * * * \\
(16.41)\end{array}$ & $\begin{array}{c}0.787 * * * \\
(19.53)\end{array}$ \\
\hline lgdppc & $\begin{array}{l}2.705 \\
(1.02)\end{array}$ & $\begin{array}{l}-2.154 \\
(-1.11)\end{array}$ & $\begin{array}{l}-1.634 \\
(-1.14)\end{array}$ & $\begin{array}{l}-0.319 \\
(-0.75)\end{array}$ & $\begin{array}{l}-2.036 \\
(-1.14)\end{array}$ & $\begin{array}{l}-1.848 \\
(-1.60)\end{array}$ & $\begin{array}{l}0.000 \\
(0.00)\end{array}$ & $\begin{array}{l}0.105 \\
(0.09)\end{array}$ & $\begin{array}{l}-0.200 \\
(-0.17)\end{array}$ & $\begin{array}{l}-2.611 \\
(-1.29)\end{array}$ & $\begin{array}{l}0.494 \\
(0.34)\end{array}$ \\
\hline gdphp & $\begin{array}{l}0.137 \\
(2.21)\end{array}$ & $\begin{array}{l}-0.062 \\
(-1.35)\end{array}$ & $\begin{array}{c}0.115 * * * \\
(3.26)\end{array}$ & $\begin{array}{l}-0.000 \\
(-0.00)\end{array}$ & $\begin{array}{l}-0.066 \\
(-1.56)\end{array}$ & $\begin{array}{c}0.084 * * * \\
(3.08)\end{array}$ & $\begin{array}{l}0.017 \\
(1.11)\end{array}$ & $\begin{array}{l}0.008 \\
(0.27)\end{array}$ & $\begin{array}{l}-0.008 \\
(-0.28)\end{array}$ & $\begin{array}{l}0.067 \\
(1.23)\end{array}$ & $\begin{array}{l}-0.044 \\
(-0.94)\end{array}$ \\
\hline pop65+ & $\begin{array}{c}0.525 * * * \\
(3.68)\end{array}$ & $\begin{array}{l}-0.076 \\
(-0.58)\end{array}$ & $\begin{array}{c}0.330 * * \\
(2.47)\end{array}$ & $\begin{array}{l}-0.027 \\
(-0.62)\end{array}$ & $\begin{array}{l}-0.092 \\
(-0.71)\end{array}$ & $\begin{array}{l}0.183^{*} \\
(1.68)\end{array}$ & $\begin{array}{l}0.008 \\
(0.21)\end{array}$ & $\begin{array}{l}-0.075 \\
(-0.65)\end{array}$ & $\begin{array}{l}0.143 \\
(1.44)\end{array}$ & $\begin{array}{l}-0.174 \\
(-0.95)\end{array}$ & $\begin{array}{c}-0.216^{*} \\
(-1.66)\end{array}$ \\
\hline pop1564 & $\begin{array}{c}0.311 * * * \\
(2.67)\end{array}$ & $\begin{array}{l}-0.113 \\
(-1.19)\end{array}$ & $\begin{array}{l}0.108 \\
(1.22)\end{array}$ & $\begin{array}{l}-0.004 \\
(-0.14)\end{array}$ & $\begin{array}{l}-0.109 \\
(-1.21)\end{array}$ & $\begin{array}{c}0.149 * * \\
(2.05)\end{array}$ & $\begin{array}{l}0.000 \\
(0.01)\end{array}$ & $\begin{array}{l}0.001 \\
(0.01)\end{array}$ & $\begin{array}{l}0.057 \\
(0.74)\end{array}$ & $\begin{array}{l}0.102 \\
(0.86)\end{array}$ & $\begin{array}{l}-0.002 \\
(-0.02)\end{array}$ \\
\hline trade & $\begin{array}{c}0.032 * \\
(1.88)\end{array}$ & $\begin{array}{c}-0.069 * * * \\
(-4.72)\end{array}$ & $\begin{array}{c}-0.038 * * * \\
(-3.60)\end{array}$ & $\begin{array}{l}-0.004 \\
(-0.80)\end{array}$ & $\begin{array}{c}-0.063 * * * \\
(-5.19)\end{array}$ & $\begin{array}{c}-0.021 * * \\
(-2.46)\end{array}$ & $\begin{array}{c}-0.011 * * \\
(-2.40)\end{array}$ & $\begin{array}{l}0.011 \\
(0.87)\end{array}$ & $\begin{array}{l}-0.013 \\
(-1.04)\end{array}$ & $\begin{array}{l}0.007 \\
(0.47)\end{array}$ & $\begin{array}{l}0.002 \\
(0.15)\end{array}$ \\
\hline$R^{2}$ & 0.657 & 0.875 & 0.839 & 0.664 & 0.905 & 0.776 & 0.735 & 0.773 & 0.779 & 0.697 & 0.693 \\
\hline$N$ & 469 & 474 & 474 & 464 & 464 & 473 & 481 & 464 & 464 & 473 & 473 \\
\hline $\begin{array}{l}\text { Avg. time } \\
\text { series length }\end{array}$ & 24.7 & 24.9 & 24.9 & 24.4 & 24.4 & 24.9 & 25.3 & 24.4 & 24.4 & 24.9 & 24.9 \\
\hline Specificatio & & & & & & & & & & & \\
\hline $\mathrm{N}_{1}$ & 0.000 & 0.000 & 0.000 & 0.000 & 0.000 & 0.000 & 0.000 & 0.000 & 0.000 & 0.000 & 0.000 \\
\hline $\mathrm{N}_{2}$ & 0.000 & 0.000 & 0.000 & 0.128 & 0.000 & 0.000 & 0.000 & 0.271 & 0.438 & 0.153 & 0.680 \\
\hline
\end{tabular}


“Table 4B. Robustness: regression in First differences”

\begin{tabular}{|c|c|c|c|c|c|c|c|c|c|c|c|}
\hline & \multicolumn{7}{|c|}{ Fiscal variables scaled to GDP } & \multicolumn{2}{|c|}{$\begin{array}{c}\text { Spending variables scaled to } \\
\text { total expenditures }\end{array}$} & \multicolumn{2}{|c|}{$\begin{array}{c}\text { Tax variables scaled to total } \\
\text { revenues }\end{array}$} \\
\hline & (1) & (2) & (3) & (4) & (5) & (6) & (7) & $(8)$ & $(9)$ & $(10)$ & $(11)$ \\
\hline Method & FD & FD & FD & FD & FD & FD & FD & FD & FD & FD & FD \\
\hline $\begin{array}{c}\text { Dependent } \\
\text { variable }\end{array}$ & fd_balance & fd_expenditures & fd_revenues & fd_capital & fd_current & fd_direct & fd_indirect & fd_capital_exp & fd_current_exp & fd_direct_rev & fd_indirect_rev \\
\hline elec & $\begin{array}{l}-0.186 \\
(-1.09)\end{array}$ & $\begin{array}{l}0.001 \\
(0.01)\end{array}$ & $\begin{array}{c}-0.286^{* *} \\
(-2.40)\end{array}$ & $\begin{array}{c}-0.102 * * \\
(-2.54)\end{array}$ & $\begin{array}{l}0.107 \\
(0.87)\end{array}$ & $\begin{array}{c}-0.297 * * * \\
(-2.85)\end{array}$ & $\begin{array}{l}-0.018 \\
(-0.37)\end{array}$ & $\begin{array}{c}-0.274 * * * \\
(-2.63)\end{array}$ & $\begin{array}{l}0.270^{* *} \\
(2.46)\end{array}$ & $\begin{array}{c}-0.348^{*} \\
(-1.84)\end{array}$ & $\begin{array}{l}0.203 \\
(1.24)\end{array}$ \\
\hline fd_lgdppc & $\begin{array}{l}23.549 * * * \\
\quad(2.60)\end{array}$ & $\begin{array}{l}-26.870 * * * \\
(-5.34)\end{array}$ & $\begin{array}{l}-0.883 \\
(-0.21)\end{array}$ & $\begin{array}{l}-1.460 \\
(-1.12)\end{array}$ & $\begin{array}{l}-26.684 * * * \\
(-6.11)\end{array}$ & $\begin{array}{l}-0.072 \\
(-0.02)\end{array}$ & $\begin{array}{l}1.013 \\
(0.60)\end{array}$ & $\begin{array}{l}1.277 \\
(0.38)\end{array}$ & $\begin{array}{l}-1.873 \\
(-0.48)\end{array}$ & $\begin{array}{l}1.605 \\
(0.26)\end{array}$ & $\begin{array}{l}2.555 \\
(0.47)\end{array}$ \\
\hline fd_growth & $\begin{array}{c}-0.134^{*} \\
(-1.86)\end{array}$ & $\begin{array}{l}-0.050 \\
(-1.22)\end{array}$ & $\begin{array}{c}-0.126^{* * *} \\
(-3.78)\end{array}$ & $\begin{array}{l}-0.006 \\
(-0.61)\end{array}$ & $\begin{array}{l}-0.036 \\
(-1.03)\end{array}$ & $\begin{array}{c}-0.106^{* * * *} \\
(-4.09)\end{array}$ & $\begin{array}{c}-0.031 * * \\
(-2.24)\end{array}$ & $\begin{array}{l}0.009 \\
(0.34)\end{array}$ & $\begin{array}{l}0.001 \\
(0.02)\end{array}$ & $\begin{array}{c}-0.121 * * \\
(-2.42)\end{array}$ & $\begin{array}{l}0.047 \\
(1.07)\end{array}$ \\
\hline$R^{2}$ & 0.237 & 0.428 & 0.148 & 0.101 & 0.477 & 0.130 & 0.097 & 0.074 & 0.060 & 0.087 & 0.064 \\
\hline$N$ & 469 & 474 & 474 & 464 & 464 & 473 & 481 & 464 & 464 & 473 & 473 \\
\hline $\begin{array}{l}\text { Avg. time series } \\
\text { length }\end{array}$ & 24.7 & 24.9 & 24.9 & 24.4 & 24.4 & 24.9 & 25.3 & 24.4 & 24.4 & 24.9 & 24.9 \\
\hline Specification tests & & & & & & & & & & & \\
\hline $\mathrm{N}_{1}$ & 0.000 & 0.000 & 0.000 & 0.000 & 0.000 & 0.000 & 0.000 & 0.000 & 0.000 & 0.000 & 0.000 \\
\hline $\mathrm{N}_{2}$ & 0.000 & 0.000 & 0.013 & 0.149 & 0.000 & 0.254 & 0.000 & 0.104 & 0.273 & 0.216 & 0.499 \\
\hline
\end{tabular}


“Table 4C. Robustness: Testing for outliers”

\begin{tabular}{|c|c|c|c|}
\hline & $\begin{array}{l}\text { Fiscal variables } \\
\text { scaled to GDP }\end{array}$ & \multicolumn{2}{|c|}{$\begin{array}{c}\text { Spending variables scaled to total } \\
\text { expenditures }\end{array}$} \\
\hline & $(1)$ & $(2)$ & (3) \\
\hline Method & FE & $\mathrm{FE}$ & $\mathrm{FE}$ \\
\hline $\begin{array}{l}\text { Dependent } \\
\text { variable }\end{array}$ & capital & capital_exp & current_exp \\
\hline elec & $\begin{array}{c}-0.063 * \\
(-1.75)\end{array}$ & $\begin{array}{c}-0.180 * * \\
(-1.97)\end{array}$ & $\begin{array}{c}0.175 * \\
(1.80)\end{array}$ \\
\hline $\mathbf{Y}_{\mathrm{t}-1}$ & $\begin{array}{c}0.695 * * * \\
(17.94)\end{array}$ & $\begin{array}{c}0.725 * * * \\
(20.55)\end{array}$ & $\begin{array}{c}0.713 * * * \\
(19.31)\end{array}$ \\
\hline lgdppc & $\begin{array}{l}0.445 \\
(1.47)\end{array}$ & $\begin{array}{l}1.372 \\
(1.60)\end{array}$ & $\begin{array}{c}-1.590 * \\
(-1.67)\end{array}$ \\
\hline growth & $\begin{array}{c}-0.023 * * \\
(-2.28)\end{array}$ & $\begin{array}{l}0.013 \\
(0.49)\end{array}$ & $\begin{array}{l}-0.012 \\
(-0.40)\end{array}$ \\
\hline$R^{2}$ & 0.680 & 0.784 & 0.778 \\
\hline$N$ & 458 & 454 & 451 \\
\hline Avg. time series length & 24.1 & 23.9 & 23.7 \\
\hline \multicolumn{4}{|l|}{ Specification tests } \\
\hline $\mathrm{N}_{1}$ & 0.000 & 0.000 & 0.000 \\
\hline $\mathrm{N}_{2}$ & 0.038 & 0.063 & 0.040 \\
\hline \multicolumn{4}{|c|}{$\begin{array}{l}\text { Notes: t-statistics, calculated using White's heteroskedasticity robust standard errors, are reported in parentheses. Regressions } \\
\text { are estimated after using Hadi (1994) method to identify and eliminate outlier observations. *** denotes significance at } 1 \% \\
\text { level, ** denotes significance at } 5 \% \text { level and * denotes significance at } 10 \% \text { level. All regressions include country and time } \\
\text { intercepts. } \\
N_{1}=\text { Likelihood ratio test for groupwise heteroskedasticity } \\
N_{2}=\text { F-test time } \\
\text { P-values are reported for the respective tests }\end{array}$} \\
\hline
\end{tabular}


“Table 5A. Robustness: Alternative control variables"

\begin{tabular}{|c|c|c|c|c|c|c|c|c|c|c|c|}
\hline & \multicolumn{7}{|c|}{ Fiscal variables scaled to GDP } & \multicolumn{2}{|c|}{$\begin{array}{c}\text { Spending variables scaled } \\
\text { to total expenditures }\end{array}$} & \multicolumn{2}{|c|}{$\begin{array}{c}\text { Tax variables scaled to } \\
\text { total revenues }\end{array}$} \\
\hline & (1) & (2) & (3) & (4) & (5) & (6) & (7) & (8) & $(9)$ & $(10)$ & $(11)$ \\
\hline $\begin{array}{c}\text { Method } \\
\text { Dependent } \\
\text { variable }\end{array}$ & $\begin{array}{c}\text { FE } \\
\text { balance }\end{array}$ & $\begin{array}{c}\text { FE } \\
\text { expenditures }\end{array}$ & $\begin{array}{c}\mathrm{FE} \\
\text { revenues }\end{array}$ & $\begin{array}{c}\mathrm{FE} \\
\text { capital }\end{array}$ & $\begin{array}{c}\text { FE } \\
\text { current }\end{array}$ & $\begin{array}{c}\mathrm{FE} \\
\text { direct }\end{array}$ & $\begin{array}{c}\mathrm{FE} \\
\text { indirect }\end{array}$ & $\begin{array}{c}\text { FE } \\
\text { capital_exp }\end{array}$ & $\begin{array}{c}\text { FE } \\
\text { current_exp }\end{array}$ & $\begin{array}{c}\text { FE } \\
\text { direct_rev }\end{array}$ & $\begin{array}{c}\text { FE } \\
\text { indirect_rev }\end{array}$ \\
\hline elec_pred & $\begin{array}{l}-0.069 \\
(-0.32)\end{array}$ & $\begin{array}{l}-0.114 \\
(-0.70)\end{array}$ & $\begin{array}{c}-0.345 * * * \\
(-2.67)\end{array}$ & $\begin{array}{c}-0.110 * * \\
(-2.32)\end{array}$ & $\begin{array}{l}0.013 \\
(0.09)\end{array}$ & $\begin{array}{c}-0.358 * * * \\
(-3.08)\end{array}$ & $\begin{array}{l}-0.007 \\
(-0.12)\end{array}$ & $\begin{array}{c}-0.291 * * \\
(-2.48)\end{array}$ & $\begin{array}{l}0.244 * \\
(1.93)\end{array}$ & $\begin{array}{c}-0.406^{*} \\
(-1.88)\end{array}$ & $\begin{array}{l}0.267 \\
(1.45)\end{array}$ \\
\hline elec_end & $\begin{array}{c}-0.400 * \\
(-1.77) \\
\end{array}$ & $\begin{array}{l}0.160 \\
(0.61)\end{array}$ & $\begin{array}{l}-0.203 \\
(-1.11)\end{array}$ & $\begin{array}{l}-0.027 \\
(-0.47)\end{array}$ & $\begin{array}{l}0.196 \\
(0.83)\end{array}$ & $\begin{array}{l}-0.188 \\
(-1.24)\end{array}$ & $\begin{array}{l}-0.053 \\
(-0.72)\end{array}$ & $\begin{array}{l}-0.115 \\
(-0.82)\end{array}$ & $\begin{array}{l}0.142 \\
(1.01)\end{array}$ & $\begin{array}{l}-0.224 \\
(-0.70)\end{array}$ & $\begin{array}{l}0.045 \\
(0.18)\end{array}$ \\
\hline elec $_{\mathrm{t} \_p r e d \_2}$ & $\begin{array}{l}-0.076 \\
(-0.23)\end{array}$ & $\begin{array}{l}-0.178 \\
(-0.69)\end{array}$ & $\begin{array}{c}-0.405^{* *} \\
(-1.99)\end{array}$ & $\begin{array}{c}-0.183 * * * \\
(-2.66)\end{array}$ & $\begin{array}{l}-0.002 \\
(-0.01)\end{array}$ & $\begin{array}{c}-0.420 * * \\
(-2.17)\end{array}$ & $\begin{array}{l}0.033 \\
(0.38)\end{array}$ & $\begin{array}{c}-0.519 * * * \\
(-2.88)\end{array}$ & $\begin{array}{l}0.368^{*} \\
(1.87)\end{array}$ & $\begin{array}{l}-0.414 \\
(-1.17)\end{array}$ & $\begin{array}{l}0.318 \\
(1.15)\end{array}$ \\
\hline 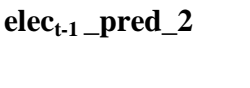 & $\begin{array}{l}-0.290 \\
(-0.79)\end{array}$ & $\begin{array}{l}-0.308 \\
(-1.07)\end{array}$ & $\begin{array}{l}-0.348 \\
(-1.33)\end{array}$ & $\begin{array}{l}-0.069 \\
(-0.73)\end{array}$ & $\begin{array}{l}-0.183 \\
(-0.66)\end{array}$ & $\begin{array}{l}-0.004 \\
(-0.02)\end{array}$ & $\begin{array}{l}-0.073 \\
(-0.51)\end{array}$ & $\begin{array}{l}-0.274 \\
(-1.03)\end{array}$ & $\begin{array}{l}0.223 \\
(0.81)\end{array}$ & $\begin{array}{l}0.548 \\
(1.15)\end{array}$ & $\begin{array}{l}-0.126 \\
(-0.28)\end{array}$ \\
\hline elect_end_2 & $\begin{array}{c}-0.727 * * \\
(-2.39)\end{array}$ & $\begin{array}{l}0.593^{*} \\
(1.68)\end{array}$ & $\begin{array}{l}-0.000 \\
(-0.00)\end{array}$ & $\begin{array}{l}0.006 \\
(0.08)\end{array}$ & $\begin{array}{c}0.595^{*} \\
(1.86)\end{array}$ & $\begin{array}{l}0.016 \\
(0.08)\end{array}$ & $\begin{array}{l}-0.069 \\
(-0.77)\end{array}$ & $\begin{array}{l}-0.136 \\
(-0.73)\end{array}$ & $\begin{array}{l}0.154 \\
(0.82)\end{array}$ & $\begin{array}{l}0.005 \\
(0.01)\end{array}$ & $\begin{array}{l}-0.234 \\
(-0.77)\end{array}$ \\
\hline 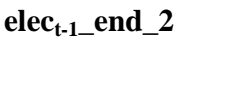 & $\begin{array}{l}0.090 \\
(0.18)\end{array}$ & $\begin{array}{l}0.445 \\
(1.13)\end{array}$ & $\begin{array}{l}0.539^{*} \\
(1.66)\end{array}$ & $\begin{array}{l}0.135 \\
(0.82)\end{array}$ & $\begin{array}{l}0.184 \\
(0.55)\end{array}$ & $\begin{array}{l}0.508 \\
(1.59)\end{array}$ & $\begin{array}{l}-0.261^{*} \\
(-1.87)\end{array}$ & $\begin{array}{l}0.228 \\
(0.50)\end{array}$ & $\begin{array}{l}-0.396 \\
(-0.96)\end{array}$ & $\begin{array}{l}0.474 \\
(0.75)\end{array}$ & $\begin{array}{c}-1.410^{* * * *} \\
(-3.11)\end{array}$ \\
\hline
\end{tabular}


“Table 5B. Robustness: regression in First differences"

\begin{tabular}{|c|c|c|c|c|c|c|c|c|c|c|c|}
\hline & \multicolumn{7}{|c|}{ Fiscal variables scaled to GDP } & \multicolumn{2}{|c|}{$\begin{array}{c}\text { Spending variables scaled } \\
\text { to total expenditures }\end{array}$} & \multicolumn{2}{|c|}{$\begin{array}{c}\text { Tax variables scaled to } \\
\text { total revenues }\end{array}$} \\
\hline & (1) & (2) & (3) & (4) & (5) & (6) & (7) & $(8)$ & $(9)$ & $(10)$ & $(11)$ \\
\hline Method & FD & FD & FD & FD & FD & FD & FD & FD & FD & FD & FD \\
\hline $\begin{array}{l}\text { Dependent } \\
\text { variable }\end{array}$ & balance & expenditures & revenues & capital & current & direct & indirect & capital_exp & current_exp & direct_rev & indirect_rev \\
\hline elec_pred & $\begin{array}{l}-0.069 \\
(-0.32)\end{array}$ & $\begin{array}{l}-0.139 \\
(-0.98)\end{array}$ & $\begin{array}{c}-0.371 * * * \\
(-2.78)\end{array}$ & $\begin{array}{c}-0.122 * * \\
(-2.49)\end{array}$ & $\begin{array}{l}0.007 \\
(0.06)\end{array}$ & $\begin{array}{c}-0.381 * * * \\
(-3.20)\end{array}$ & $\begin{array}{l}-0.033 \\
(-0.61)\end{array}$ & $\begin{array}{c}-0.303 * * \\
(-2.45)\end{array}$ & $\begin{array}{c}0.266 * * \\
(1.99)\end{array}$ & $\begin{array}{c}-0.421 * * \\
(-2.02)\end{array}$ & $\begin{array}{l}0.229 \\
(1.29)\end{array}$ \\
\hline elec_end & $\begin{array}{c}-0.359^{*} \\
(-1.69)\end{array}$ & $\begin{array}{l}0.207 \\
(0.91)\end{array}$ & $\begin{array}{l}-0.161 \\
(-0.90)\end{array}$ & $\begin{array}{l}-0.071 \\
(-1.30)\end{array}$ & $\begin{array}{l}0.258 \\
(1.22)\end{array}$ & $\begin{array}{l}-0.173 \\
(-1.15)\end{array}$ & $\begin{array}{l}0.004 \\
(0.05)\end{array}$ & $\begin{array}{l}-0.230 \\
(-1.62)\end{array}$ & $\begin{array}{c}0.277 * * \\
(2.01) \\
\end{array}$ & $\begin{array}{l}-0.240 \\
(-0.79)\end{array}$ & $\begin{array}{l}0.164 \\
(0.64)\end{array}$ \\
\hline elec $_{\text {t_pred_2 }}$ & $\begin{array}{l}-0.022 \\
(-0.07)\end{array}$ & $\begin{array}{l}-0.262 \\
(-1.14)\end{array}$ & $\begin{array}{c}-0.449 * * \\
(-2.08)\end{array}$ & $\begin{array}{c}-0.196 * * * \\
(-2.65)\end{array}$ & $\begin{array}{l}-0.061 \\
(-0.32)\end{array}$ & $\begin{array}{c}-0.424 * * \\
(-2.20)\end{array}$ & $\begin{array}{l}-0.030 \\
(-0.36)\end{array}$ & $\begin{array}{c}-0.535^{* * * *} \\
(-2.75)\end{array}$ & $\begin{array}{c}0.385^{*} \\
(1.78)\end{array}$ & $\begin{array}{l}-0.338 \\
(-1.03)\end{array}$ & $\begin{array}{l}0.173 \\
(0.67)\end{array}$ \\
\hline 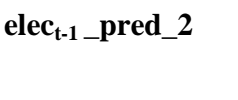 & $\begin{array}{l}-0.426 \\
(-1.10)\end{array}$ & $\begin{array}{l}-0.129 \\
(-0.39)\end{array}$ & $\begin{array}{l}-0.237 \\
(-0.86)\end{array}$ & $\begin{array}{l}-0.076 \\
(-0.73)\end{array}$ & $\begin{array}{l}0.014 \\
(0.05)\end{array}$ & $\begin{array}{l}0.056 \\
(0.24)\end{array}$ & $\begin{array}{l}-0.058 \\
(-0.43)\end{array}$ & $\begin{array}{l}-0.316 \\
(-1.08)\end{array}$ & $\begin{array}{l}0.294 \\
(0.98)\end{array}$ & $\begin{array}{l}0.496 \\
(1.03)\end{array}$ & $\begin{array}{l}-0.141 \\
(-0.32)\end{array}$ \\
\hline elec $\_$_end_2 & $\begin{array}{c}-0.653 * * \\
(-2.14)\end{array}$ & $\begin{array}{c}0.532 * \\
(1.67)\end{array}$ & $\begin{array}{l}-0.078 \\
(-0.32)\end{array}$ & $\begin{array}{l}-0.063 \\
(-0.88)\end{array}$ & $\begin{array}{c}0.584 * * \\
(2.02)\end{array}$ & $\begin{array}{l}-0.055 \\
(-0.30)\end{array}$ & $\begin{array}{l}-0.004 \\
(-0.04)\end{array}$ & $\begin{array}{l}-0.300 \\
(-1.58)\end{array}$ & $\begin{array}{c}0.340^{*} \\
(1.79)\end{array}$ & $\begin{array}{l}-0.054 \\
(-0.12)\end{array}$ & $\begin{array}{l}0.001 \\
(0.00)\end{array}$ \\
\hline 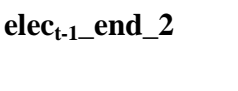 & $\begin{array}{l}0.421 \\
(0.90)\end{array}$ & $\begin{array}{l}0.307 \\
(0.80)\end{array}$ & $\begin{array}{l}0.573^{*} \\
(1.70)\end{array}$ & $\begin{array}{l}0.070 \\
(0.41)\end{array}$ & $\begin{array}{l}0.071 \\
(0.22)\end{array}$ & $\begin{array}{l}0.486 \\
(1.60)\end{array}$ & $\begin{array}{l}-0.157 \\
(-1.10)\end{array}$ & $\begin{array}{l}0.177 \\
(0.37)\end{array}$ & $\begin{array}{l}-0.386 \\
(-0.95)\end{array}$ & $\begin{array}{l}0.297 \\
(0.48)\end{array}$ & $\begin{array}{l}-1.168 * * * \\
(-2.82)\end{array}$ \\
\hline
\end{tabular}


“Table 5C. Robustness: Testing for outliers"

\begin{tabular}{|c|c|c|c|}
\hline \multirow{4}{*}{$\begin{array}{c} \\
\text { Method } \\
\text { Dependent } \\
\text { variable }\end{array}$} & \multirow{2}{*}{$\begin{array}{c}\begin{array}{c}\text { Fiscal variables } \\
\text { scaled to GDP }\end{array} \\
(2)\end{array}$} & \multicolumn{2}{|c|}{ Spending variables scaled to total expenditures } \\
\hline & & (4) & (4) \\
\hline & $\mathrm{FE}$ & FE & $\mathrm{FE}$ \\
\hline & capital & capital_exp & current_exp \\
\hline elec_pred & $\begin{array}{c}-0.089 * * \\
(-2.08)\end{array}$ & $\begin{array}{c}-0.238 * * \\
(-2.21)\end{array}$ & $\begin{array}{c}0.210^{*} \\
(1.79)\end{array}$ \\
\hline elec_end & $\begin{array}{l}-0.022 \\
(-0.39)\end{array}$ & $\begin{array}{l}-0.082 \\
(-0.59)\end{array}$ & $\begin{array}{l}0.117 \\
(0.83) \\
\end{array}$ \\
\hline elec $_{t} \_$pred_2 & $\begin{array}{c}-0.156 * * \\
(-2.53)\end{array}$ & $\begin{array}{c}-0.458 * * * \\
(-2.72)\end{array}$ & $\begin{array}{c}0.353 * \\
(1.92)\end{array}$ \\
\hline 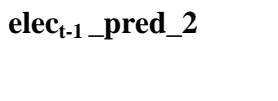 & $\begin{array}{l}-0.053 \\
(-0.56)\end{array}$ & $\begin{array}{l}-0.284 \\
(-1.13)\end{array}$ & $\begin{array}{l}0.248 \\
(0.95)\end{array}$ \\
\hline elec $\_$_end_2 & $\begin{array}{l}0.008 \\
(0.12)\end{array}$ & $\begin{array}{l}-0.117 \\
(-0.67)\end{array}$ & $\begin{array}{l}0.126 \\
(0.70)\end{array}$ \\
\hline 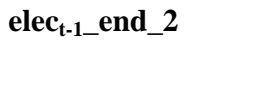 & $\begin{array}{l}0.047 \\
(0.37)\end{array}$ & $\begin{array}{l}-0.195 \\
(-0.56)\end{array}$ & $\begin{array}{l}0.001 \\
(0.00)\end{array}$ \\
\hline
\end{tabular}

Notes: see Table 4C. 


\section{CESifo Working Paper Series}

for full list see www.cesifo-group.org/wp

(address: Poschingerstr. 5, 81679 Munich, Germany, office@cesifo.de)

2845 Guglielmo Maria Caporale, Burcu Erdogan and Vladimir Kuzin, Testing for Convergence in Stock Markets: A Non-Linear Factor Approach, November 2009

2846 Michèle Belot and Jan Fidrmuc, Anthropometry of Love - Height and Gender Asymmetries in Interethnic Marriages, November 2009

2847 Volker Nitsch and Nikolaus Wolf, Tear Down this Wall: On the Persistence of Borders in Trade, November 2009

2848 Jan K. Brueckner and Stef Proost, Carve-Outs Under Airline Antitrust Immunity, November 2009

2849 Margarita Katsimi and Vassilis Sarantides, The Impact of Fiscal Policy on Profits, November 2009

2850 Scott Alan Carson, The Relationship between Stature and Insolation: Evidence from Soldiers and Prisoners, November 2009

2851 Horst Raff and Joachim Wagner, Intra-Industry Adjustment to Import Competition: Theory and Application to the German Clothing Industry, November 2009

2852 Erkki Koskela, Impacts of Labor Taxation with Perfectly and Imperfectly Competitive Labor Markets under Flexible Outsourcing, November 2009

2853 Cletus C. Coughlin and Dennis Novy, Is the International Border Effect Larger than the Domestic Border Effect? Evidence from U.S. Trade, November 2009

2854 Johannes Becker and Clemens Fuest, Source versus Residence Based Taxation with International Mergers and Acquisitions, November 2009

2855 Andreas Hoffmann and Gunther Schnabl, A Vicious Cycle of Manias, Crashes and Asymmetric Policy Responses - An Overinvestment View, November 2009

2856 Xavier Vives, Strategic Supply Function Competition with Private Information, November 2009

2857 M. Hashem Pesaran and Paolo Zaffaroni, Optimality and Diversifiability of Mean Variance and Arbitrage Pricing Portfolios, November 2009

2858 Davide Sala, Philipp J.H. Schröder and Erdal Yalcin, Market Access through Bound Tariffs, November 2009

2859 Ben J. Heijdra and Pim Heijnen, Environmental Policy and the Macroeconomy under Shallow-Lake Dynamics, November 2009 
2860 Enrico Spolaore, National Borders, Conflict and Peace, November 2009

2861 Nina Czernich, Oliver Falck, Tobias Kretschmer and Ludger Woessmann, Broadband Infrastructure and Economic Growth, December 2009

2862 Evžen Kočenda and Martin Vojtek, Default Predictors and Credit Scoring Models for Retail Banking, December 2009

2863 Christian Gollier and Martin L. Weitzman, How Should the Distant Future be Discounted when Discount Rates are Uncertain?, December 2009

2864 Tiberiu Dragu and Mattias Polborn, Terrorism Prevention and Electoral Accountability, December 2009

2865 Torfinn Harding and Beata Smarzynska Javorcik, A Touch of Sophistication: FDI and Unit Values of Exports, December 2009

2866 Matthias Dischinger and Nadine Riedel, There's no Place like Home: The Profitability Gap between Headquarters and their Foreign Subsidiaries, December 2009

2867 Andreas Haufler and Frank Stähler, Tax Competition in a Simple Model with Heterogeneous Firms: How Larger Markets Reduce Profit Taxes, December 2009

2868 Steinar Holden, Do Choices Affect Preferences? Some Doubts and New Evidence, December 2009

2869 Alberto Asquer, On the many Ways Europeanization Matters: The Implementation of the Water Reform in Italy (1994-2006), December 2009

2870 Choudhry Tanveer Shehzad and Jakob De Haan, Financial Reform and Banking Crises, December 2009

2871 Annette Alstadsæter and Hans Henrik Sievertsen, The Consumption Value of Higher Education, December 2009

2872 Chris van Klaveren, Bernard van Praag and Henriette Maassen van den Brink, Collective Labor Supply of Native Dutch and Immigrant Households in the Netherlands, December 2009

2873 Burkhard Heer and Alfred Maußner, Computation of Business-Cycle Models with the Generalized Schur Method, December 2009

2874 Carlo Carraro, Enrica De Cian and Massimo Tavoni, Human Capital Formation and Global Warming Mitigation: Evidence from an Integrated Assessment Model, December 2009

2875 André Grimaud, Gilles Lafforgue and Bertrand Magné, Climate Change Mitigation Options and Directed Technical Change: A Decentralized Equilibrium Analysis, December 2009 
2876 Angel de la Fuente, A Mixed Splicing Procedure for Economic Time Series, December 2009

2877 Martin Schlotter, Guido Schwerdt and Ludger Woessmann, Econometric Methods for Causal Evaluation of Education Policies and Practices: A Non-Technical Guide, December 2009

2878 Mathias Dolls, Clemens Fuest and Andreas Peichl, Automatic Stabilizers and Economic Crisis: US vs. Europe, December 2009

2879 Tom Karkinsky and Nadine Riedel, Corporate Taxation and the Choice of Patent Location within Multinational Firms, December 2009

2880 Kai A. Konrad, Florian Morath and Wieland Müller, Taxation and Market Power, December 2009

2881 Marko Koethenbuerger and Michael Stimmelmayr, Corporate Taxation and Corporate Governance, December 2009

2882 Gebhard Kirchgässner, The Lost Popularity Function: Are Unemployment and Inflation no longer Relevant for the Behaviour of Germany Voters?, December 2009

2883 Marianna Belloc and Ugo Pagano, Politics-Business Interaction Paths, December 2009

2884 Wolfgang Buchholz, Richard Cornes and Dirk Rübbelke, Existence and Warr Neutrality for Matching Equilibria in a Public Good Economy: An Aggregative Game Approach, December 2009

2885 Charles A.E. Goodhart, Carolina Osorio and Dimitrios P. Tsomocos, Analysis of Monetary Policy and Financial Stability: A New Paradigm, December 2009

2886 Thomas Aronsson and Erkki Koskela, Outsourcing, Public Input Provision and Policy Cooperation, December 2009

2887 Andreas Ortmann, "The Way in which an Experiment is Conducted is Unbelievably Important": On the Experimentation Practices of Economists and Psychologists, December 2009

2888 Andreas Irmen, Population Aging and the Direction of Technical Change, December 2009

2889 Wolf-Heimo Grieben and Fuat Şener, Labor Unions, Globalization, and Mercantilism, December 2009

2890 Conny Wunsch, Optimal Use of Labor Market Policies: The Role of Job Search Assistance, December 2009

2891 Claudia Buch, Cathérine Tahmee Koch and Michael Kötter, Margins of International Banking: Is there a Productivity Pecking Order in Banking, too?, December 2009 
2892 Shafik Hebous and Alfons J. Weichenrieder, Debt Financing and Sharp Currency Depreciations: Wholly vs. Partially Owned Multinational Affiliates, December 2009

2893 Johannes Binswanger and Daniel Schunk, What is an Adequate Standard of Living during Retirement?, December 2009

2894 Armin Falk and James J. Heckman, Lab Experiments are a Major Source of Knowledge in the Social Sciences, December 2009

2895 Hartmut Egger and Daniel Etzel, The Impact of Trade on Employment, Welfare, and Income Distribution in Unionized General Oligopolistic Equilibrium, December 2009

2896 Julian Rauchdobler, Rupert Sausgruber and Jean-Robert Tyran, Voting on Thresholds for Public Goods: Experimental Evidence, December 2009

2897 Michael McBride and Stergios Skaperdas, Conflict, Settlement, and the Shadow of the Future, December 2009

2898 Ben J. Heijdra and Laurie S. M. Reijnders, Economic Growth and Longevity Risk with Adverse Selection, December 2009

2899 Johannes Becker, Taxation of Foreign Profits with Heterogeneous Multinational Firms, December 2009

2900 Douglas Gale and Piero Gottardi, Illiquidity and Under-Valuation of Firms, December 2009

2901 Donatella Gatti, Christophe Rault and Anne-Gaël Vaubourg, Unemployment and Finance: How do Financial and Labour Market Factors Interact?, December 2009

2902 Arno Riedl, Behavioral and Experimental Economics Can Inform Public Policy: Some Thoughts, December 2009

2903 Wilhelm K. Kohler and Marcel Smolka, Global Sourcing Decisions and Firm Productivity: Evidence from Spain, December 2009

2904 Marcel Gérard and Fernando M. M. Ruiz, Corporate Taxation and the Impact of Governance, Political and Economic Factors, December 2009

2905 Mikael Priks, The Effect of Surveillance Cameras on Crime: Evidence from the Stockholm Subway, December 2009

2906 Xavier Vives, Asset Auctions, Information, and Liquidity, January 2010

2907 Edwin van der Werf, Unilateral Climate Policy, Asymmetric Backstop Adoption, and Carbon Leakage in a Two-Region Hotelling Model, January 2010

2908 Margarita Katsimi and Vassilis Sarantides, Do Elections Affect the Composition of Fiscal Policy?, January 2010 